\title{
Genome-wide mRNA expression profiling in vastus lateralis of COPD patients with low and normal fat free mass index and healthy controls
}

Roberto A Rabinovich ${ }^{1 *}$, Ellen Drost ${ }^{1}$, Jonathan R Manning ${ }^{2}$, Donald R Dunbar ${ }^{2}$, MaCarmen Díaz-Ramos ${ }^{3}$, Ramzi Lakhdar', Ricardo Bastos ${ }^{3,4 \dagger}$ and William MacNee ${ }^{1+}$

\begin{abstract}
Background: Chronic Obstructive Pulmonary Disease (COPD) has significant systemic effects beyond the lungs amongst which muscle wasting is a prominent contributor to exercise limitation and an independent predictor of morbidity and mortality. The molecular mechanisms leading to skeletal muscle dysfunction/wasting are not fully understood and are likely to be multi-factorial. The need to develop therapeutic strategies aimed at improving skeletal muscle dysfunction/wasting requires a better understanding of the molecular mechanisms responsible for these abnormalities. Microarrays are powerful tools that allow the investigation of the expression of thousands of genes, virtually the whole genome, simultaneously. We aim at identifying genes and molecular pathways involved in skeletal muscle wasting in COPD.
\end{abstract}

Methods: We assessed and compared the vastus lateralis transcriptome of COPD patients with low fat free mass index (FFMI) as a surrogate of muscle mass $\left(C^{2 O P D_{L}}\right)\left(F_{1} V_{1} 30 \pm 3.6 \%\right.$ pred, FFMI $15 \pm 0.2 \mathrm{Kg}^{-\mathrm{m}^{-2}}$ ) with patients with COPD and normal FFMI $\left(C^{-O P D}\right)\left(F E V_{1} 44 \pm 5.8 \%\right.$ pred, FFMI $\left.19 \pm 0.5 \mathrm{Kg}_{\mathrm{N}} \mathrm{m}^{-2}\right)$ and a group of age and sex matched healthy

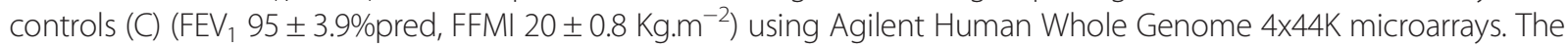
altered expression of several of these genes was confirmed by real time TaqMan PCR. Protein levels of P21 were assessed by immunoblotting.

Results: A subset of 42 genes was differentially expressed in $\mathrm{COPD}_{\mathrm{L}}$ in comparison to both $\mathrm{COPD}_{\mathrm{N}}$ and $\mathrm{C}$ (PFP $<0.05 ;-1.5 \geq F C \geq 1.5$ ). The altered expression of several of these genes was confirmed by real time TaqMan $P C R$ and correlated with different functional and structural muscle parameters. Five of these genes (CDKN1A, GADD45A, PMP22, BEX2, CGREF1, CYR61), were associated with cell cycle arrest and growth regulation and had been previously identified in studies relating muscle wasting and ageing. Protein levels of CDKN1A, a recognized marker of premature ageing/cell cycle arrest, were also found to be increased in COPD .

Conclusions: This study provides evidence of differentially expressed genes in peripheral muscle in COPD patients corresponding to relevant biological processes associated with skeletal muscle wasting and provides potential targets for future therapeutic interventions to prevent loss of muscle function and mass in COPD.

Keywords: COPD, Skeletal Muscle Dysfunction, Skeletal muscle wasting, Gene expression, Ageing

\footnotetext{
* Correspondence: roberto.rabinovich@ed.ac.uk

${ }^{\dagger}$ Equal contributors

'ELEGI Colt Laboratory, Centre for Inflammation Research, The Queen's

Medical Research Institute, University of Edinburgh, 47 Little France Crescent,

Edinburgh, Scotland EH16 4TJ, UK

Full list of author information is available at the end of the article
}

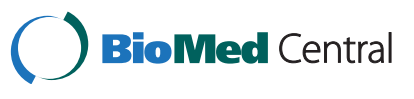

(c) 2015 Rabinovich et al.; licensee BioMed Central. This is an Open Access article distributed under the terms of the Creative Commons Attribution License (http://creativecommons.org/licenses/by/4.0), which permits unrestricted use, distribution, and reproduction in any medium, provided the original work is properly credited. The Creative Commons Public Domain Dedication waiver (http://creativecommons.org/publicdomain/zero/1.0/) applies to the data made available in this article, unless otherwise stated. 


\section{Introduction}

Chronic obstructive pulmonary disease (COPD) is associated with several extra-pulmonary effects of which skeletal muscle wasting is one of the most extensively studied [1,2] and results in loss of muscle strength [1,3-6], contributes to exercise (in)tolerance [7-10] and is a predictor of health related quality of life (HRQoL) $[11]$ and survival $[12,13]$ independent of the degree of airway obstruction [10].

Muscle wasting affects 18 to $36 \%$ of patients with COPD $[7,14]$ and can be present even in patients with normal weight $[7,14,15]$. Indeed, muscle wasting is a better predictor of health related quality of life [11] and survival $[12,13]$ than body weight itself. But why does only a subgroup of patients with COPD develop muscle wasting?; Several patho-physiological changes, have been identified in the skeletal muscle of COPD patients namely fibre size reduction (atrophy) [7], fibre type redistribution [16], altered bioenergetics [16], altered capillarization [17], and altered mitochondrial function $[18,19]$.

The molecular mechanisms leading to skeletal muscle wasting are not fully understood and are likely to be multi-factorial, including physical inactivity, systemic inflammation/oxidative stress and cell hypoxia [1] among others.

Accumulating evidence supports the idea that COPD is a disease of accelerated ageing [20]. It has recently been shown that limb muscles of patients with COPD have increased number of senescent satellite cells and an exhausted muscle regenerative capacity, compromising the maintenance of muscle mass in these individuals [21] suggesting that premature cellular senescence and subsequent exhaustion of the regenerative potential of the muscles may relate to muscle abnormalities characteristic of these patients.

Strategies to reverse skeletal muscle dysfunction/wasting achieve only relatively modest improvements [22]. There is a need to develop therapeutic strategies aimed at improving skeletal muscle dysfunction/wasting, which requires a better understanding of the molecular mechanisms responsible for these abnormalities.

Microarrays are powerful tools that allow the investigation of the expression of thousands of genes, virtually the whole genome, simultaneously. An analysis of the genes that are being transcribed in the muscle, the transcriptome, should shed light on the molecular mechanisms responsible for muscle dysfunction and wasting in COPD and can help to identify molecular targets for the development of therapeutic strategies specifically designed to improve muscle function and bulk.

In this study we assessed the transcriptome of the vastus lateralis muscle in COPD patients with low fat free mass index (FFMI) as a surrogate of muscle mass $\left(\mathrm{COPD}_{\mathrm{L}}\right)$ in comparison to patients with COPD and normal FFMI
$\left(\mathrm{COPD}_{\mathrm{N}}\right)$ and a group of age and sex matched healthy controls $(\mathrm{C})$.

We hypothesize that genes related to cell cycle arrest and inhibition of cell growth will be up-regulated while genes related to energy production and muscle development will be down-regulated in $\mathrm{COPD}_{\mathrm{L}}$. We expect similarities in the transcriptome of $\mathrm{COPD}_{\mathrm{L}}$ and muscle wasting relating to the normal ageing process. Moreover, the transcriptome analysis of this group may reveal important pathways leading to peripheral muscle wasting.

This study demonstrates that vastus lateralis of patients with COPD and muscle wasting overexpress genes related to inhibition of cell cycle and of cell growth whilst genes related to muscle formation and growth and energy production were down-regulated. This pattern is similar to observations associated with ageing, which suggests that premature ageing may play a role in muscle atrophy in COPD.

\section{Methods \\ Study group}

Nineteen stable patients with COPD, nine with low FFMI $\left(C O P D_{L}\right)$ and ten with normal FFMI $\left(C_{C O P D}\right)$, and ten age, gender and smoking status-matched healthy subjects with normal FFMI were included in the present study (Table 1). All patients had a diagnosis of COPD according to the Global Initiative for Chronic Obstructive Lung Disease [23]. They were clinically stable and free of exacerbations for 4 weeks prior to the study and free of drugs that can potentially affect the muscle (i.e. systemic corticosteroids, statins). The study was approved by the Lothian Regional Ethics Committee.

\section{Measurements \\ Assessment}

All subjects had the following baseline assessments: anthropometric measurements, body composition measurement with bioimpedance (BIA), pulmonary function tests (spirometry) and blood gases (Ciba Corning 800, USA), six-minute walking distance (6MWD) [24], quadriceps maximal voluntary contraction (QMVC) [25] (Chatillon ${ }^{\circ}$ K-MSC 500, Ametek, Florida), health-related quality of life questionnaires (St. George's Respiratory Questionnaire, SGRQ) [26], modified Medical Research Council (mMRC) dyspnoea scale and physical activity (PA) levels using the Voorrips physical activity questionnaire $\left(\mathrm{PA}_{V}\right)$ [27] and the London Chest Activity of Daily Living Scale (LCADL) [28] for patients with COPD. Number of exacerbations in the previous year was recorded.

Low FFMI was defined as $<16 \mathrm{~kg} \cdot \mathrm{m}^{-2}$ for male and $<15 \mathrm{~kg} \cdot \mathrm{m}^{-2}$ for female COPD patients [29]. 
Table 1 Characteristics of the study groups

\begin{tabular}{|c|c|c|c|c|c|c|c|}
\hline & $\mathrm{COPD}_{\mathrm{L}}$ & & $\mathrm{COPD}_{\mathrm{N}}$ & & Controls & & $\mathrm{p}$-value \\
\hline$M / F$ & $7 / 2$ & A & $8 / 2$ & A & $8 / 2$ & A & ns \\
\hline Age (Years) & $67 \pm 2.0$ & A & $69 \pm 1.5$ & A & $68 \pm 1.4$ & A & ns \\
\hline $\mathrm{BMI}\left(\mathrm{Kg} \mathrm{m}^{-2}\right)$ & $18.8 \pm 0.7$ & A & $26 \pm 0.7$ & B & $30 \pm 2.1$ & $\mathrm{C}$ & $<0.0001$ \\
\hline FFMI $\left(\mathrm{Kg} \cdot \mathrm{m}^{-2}\right)$ & $15 \pm 0.2$ & A & $19 \pm 0.5$ & B & $20 \pm 0.8$ & B & $<0.0001$ \\
\hline Active/ex-smokers & $1 / 8$ & A & $2 / 8$ & A & $2 / 8$ & A & ns \\
\hline Pack/year & $66 \pm 14$ & A & $49 \pm 6.6$ & $A B$ & $32 \pm 5.0$ & B & 0.037 \\
\hline Average cessation (years) & $6.0 \pm 2.5$ & A & $8.4 \pm 2.2$ & A & $23 \pm 5.5$ & B & $<0.01$ \\
\hline Age at smoking cessation (years) & $61.1 \pm 8.2$ & A & $60.5 \pm 7.6$ & A & $45.1 \pm 15.5$ & B & $<0.01$ \\
\hline $\mathrm{mMRC}$ & $4 \pm 0.4$ & A & $3 \pm 0.4$ & B & & & 0.038 \\
\hline $\mathrm{FEV}_{1}(\mathrm{~L})$ & $0.8 \pm 0.1$ & A & $1.2 \pm 0.1$ & A & $2.8 \pm 0.2$ & B & $<0.0001$ \\
\hline $\mathrm{FEV}_{1}$ (\% pred) & $30 \pm 3.6$ & A & $44 \pm 5.8$ & A & $95 \pm 3.9$ & B & $<0.0001$ \\
\hline FVC (L) & $2.6 \pm 0.3$ & A & $2.7 \pm 0.4$ & A & $3.9 \pm 0.2$ & B & 0.015 \\
\hline FVC (\% pred) & $76 \pm 6.4$ & A & $88 \pm 9.0$ & $A B$ & $104 \pm 3.2$ & B & 0.01 \\
\hline $\mathrm{FEV}_{1} / \mathrm{FVC}$ & $0.32 \pm 0.1$ & A & $0.38 \pm 0.1$ & A & $0.71 \pm 0.0$ & B & $<0.0001$ \\
\hline $\mathrm{PaO}_{2}(\mathrm{mmHg})$ & $79 \pm 7.4$ & A & $70 \pm 3.1$ & A & $73 \pm 1.8$ & A & ns \\
\hline $\mathrm{PaCO}_{2}(\mathrm{mmHg})$ & $43 \pm 2.0$ & A & $41 \pm 1.1$ & A & $42 \pm 0.6$ & A & ns \\
\hline Physical activity ( $($ ) & $1.2 \pm 0.3$ & A & $7 \pm 1.9$ & B & $11 \pm 1.5$ & B & $<0.0001$ \\
\hline Physical activity (L) & $43 \pm 3.6$ & A & $30 \pm 5.0$ & A & & & ns \\
\hline QMVC (N) & $213 \pm 19.4$ & A & $323 \pm 25.6$ & B & $366 \pm 26.8$ & B & 0.002 \\
\hline 6MWD (m) & $306 \pm 55$ & A & $411 \pm 50.1$ & $A B$ & $524 \pm 37.9$ & B & 0.01 \\
\hline BODE & $6.5 \pm 1.3$ & A & $4 \pm 0.9$ & A & & & ns \\
\hline SGRQ Symptoms & $76 \pm 4.8$ & A & $60 \pm 4.2$ & B & & & 0.01 \\
\hline SGRQ Activity & $86 \pm 4.7$ & A & $52 \pm 9.2$ & B & & & 0.003 \\
\hline SGRQ Impact & $57 \pm 6.6$ & A & $33 \pm 7.7$ & B & & & 0.01 \\
\hline SGRQ Total & $69 \pm 5.4$ & A & $43 \pm 6.8$ & B & & & 0.005 \\
\hline Type I Fibre (\%) & $25.1 \pm 4.6$ & A & $24.4 \pm 3.3$ & A & $38.7 \pm 3.9$ & B & 0.04 \\
\hline Type $\|$ area $\left(\mu^{2}\right)$ & $2033 \pm 166$ & A & $2978 \pm 277$ & B & $2564 \pm 277$ & $A B$ & 0.03 \\
\hline
\end{tabular}

Definition of abbreviations: $\mathrm{COPD}_{\mathrm{N}}=\mathrm{COPD}$ patients with normal $\mathrm{FFMl}$; $\mathrm{COPD}_{\mathrm{L}}=$ patients with $\mathrm{COPD}$ with low $\mathrm{FFMl}$; $\mathrm{BMI}=\mathrm{Body}$ mass index; $\mathrm{FFMI}=$ fat free mass index; $\mathrm{MRC}=$ medical research council dyspnoea score; $\mathrm{FEV}_{1}=$ forced expiratory volume in the first second; $\mathrm{FVC}=$ forced vital capacity; $\mathrm{PaO} \mathrm{O}_{2}=$ arterial oxygen partial pressure; $\mathrm{PaCO}_{2}=$ arterial carbon dioxide partial pressure; Physical Activity $(\mathrm{V})=$ Voorrips Questionnaire; Physical activity $(\mathrm{L})=$ London Chest Activity of Daily Living Scale; QMVC = quadriceps maximal voluntary contraction; 6MWD = six minute walking distance; SGRQ = St. George's Respiratory Questionnaire; ns = not significant; NA = not applicable. Comparisons among groups were done using ANOVA and Student-Newman-Keuls as a post-hoc test. Differences among the three different groups were stated using letters $A, B$ and $C$ where sharing a letter implies no differences between these groups and having a different letter implies a statistical difference in the post-hoc test.

\section{Vastus Lateralis muscle biopsy and RNA isolation}

An open muscle biopsy of the "vastus lateralis" was obtained and $\sim 0.1 \mathrm{~g}$ was included in RNA stabilization reagent (RNAlater ${ }^{\circ}$, Ambion, Inc., USA) and stored at $-20^{\circ} \mathrm{C}$ for RNA extraction. Total RNA was extracted and purified by homogenisation (TissueLyser, Qiagen Ltd. West Sussex, UK) of tissue employing the TRIzol ${ }^{\circ}$ Plus RNA Purification Kit (Invitrogen Life Technologies, Carlsbad, CA).

\section{Fibre type typification}

Paraffin sections (5um) were de-waxed and re-hydrated through graded ethanol using standard procedures. Sections were placed in $250 \mathrm{ml}$ of Novocastra $\mathrm{pH} 8$ retrieval buffer and subjected to antigen retrieval in a de-cloaking chamber (Biocare Medical, USA) using a protocol described elsewhere [30].

\section{Microarray hybridization and data analysis}

Five hundred nanograms of total RNA from each sample was converted into labelled cRNA with nucleotides coupled to a fluorescent dye (Cy3) using the Quick Amp Kit (Agilent Technologies, Palo Alto, CA). Cy3-labeled cRNA $(1.65 \mu \mathrm{g})$ was hybridized to Agilent Human Whole Genome $4 \times 44 \mathrm{~K}$ Microarrays (Agilent Technologies, Santa Clara, CA). The hybridized array was then washed and scanned and the data were extracted from 
the scanned image using Feature Extraction version 10.2 (Agilent Technologies).

Pre-processing (background correction, normalization, filtering and summarization) subsequent data processing and analysis was performed using the Agi4x44 Preprocess module from Bioconductor [31,32].

The Rank Product [33,34] was employed for the microarray data analysis. RP is a non-parametric algorithm that detects probes/genes consistently highly ranked by foldchange between samples from different groups and employs a 'percent false positives' (PFP) measure, also known as false discovery rate (FDR), to select the most significant differential expressions. A percentage of false positive (PFP) below 0.05 was considered statistically significant.

The gene functional enrichment analysis was performed using DAVID Bioinformatics Resources (http:// david.abcc.ncifcrf.gov/). Specifically, the Functional Annotation Chart tool was used to enrich the over-represented Gene Ontology (GO) terms among the differentially expressed gene list. A list of all detectable transcripts was used as the background for the GO analysis [35]. The GO terms after correction for FDR at $\mathrm{p}<0.05$ (Benjamini Hochberg) were selected for further analysis and interpretation.

Ingenuity Pathway Analysis (IPA, Ingenuity Systems, Redwood, CA) was used to further investigate the Genespring expression clusters [36].

\section{qPCR validation}

Based on microarray-derived fold-change $(>2)$ or statistical significance for differential expression and/or the biological relevance for the different comparisons, 11 genes were selected for TaqMan qPCR validation (Applied Biosystems).

\section{Western blot analysis}

P21, the protein encoded by the CDKN1A gene was determined using immunoblotting. $20 \mu \mathrm{g}$ of protein was resolved by sodium-dodecyl sulfate-polyacrylamide gel electrophoresis on $10 \%$ polyacrylamide gels. Proteins were transferred to Immobilon-P PVDF membranes (Millipore, Billerica, MA), blocked with 5\% dry milk (Bio-Rad, München, Germany) in TBS (Sigma) overnight at $4^{\circ} \mathrm{C}$ and probed with primary antibodies primary antibody against p21 (ab 7960) (Abcam, Bristol, UK) during $1 \mathrm{~h}$ at room temperature. Proteins were then visualized using the ECL Detection System (Pierce, Rockford, IL) as per the manufacturer's instructions.

\section{Statistical analysis}

Anthropometric, physiological data and immunobloting results for $\mathrm{p} 21$ are expressed as mean \pm SEM. These data were analysed using ANOVA with Student-NewmanKeuls as a post-hoc test. Correlation analysis between variables was conducted using Pearson's correlation index for continuous variables and Spearman's correlation index for categorical variables. For the qPCR validation analysis differential expression analysis on individual sample values of $\Delta C T$ using Kruskal Wallis with a Nemenyi-Damico-Wolfe-Dunn post-hoc test was performed.

The statistics were conducted using the statistical package SAS version 9.3 (SAS Institute Inc, Cary, NC, USA). A $p$ value $<0.05$ was taken as statistically significant.

Full details of the methods can be found in the Additional file 1.

\section{Results}

Anthropometric characteristics and pulmonary function data of study subjects are depicted in Table 1. Both groups of COPD patients showed airflow limitation compared to healthy controls $(\mathrm{C})$ who all had normal spirometry, but there were no differences in spirometry between $C O P D_{N}$ and $\mathrm{COPD}_{\mathrm{L}}$ (Table 1 and Additional file 2: Figure S1). Patients were matched by smoking status (two $\mathrm{COPD}_{\mathrm{N}}$, one $\mathrm{COPD}_{\mathrm{L}}$ patient and two healthy controls were active smokers at the time of inclusion, $\mathrm{p}=\mathrm{ns}$ ). All subjects, including healthy controls, were exposed (current or exsmokers) to cigarette smoking (no never-smokers were included in the study). Moreover, no differences in the number of years of smoking cessation was seen between $\mathrm{COPD}_{\mathrm{L}}(6.0 \pm 2.5$ years $)$ and $\mathrm{COPD}_{\mathrm{N}}(8.4 \pm 2.2$ years $)$ nor in the age of the patients when they stopped smoking $(61.1 \pm 8.2$ years old $) \mathrm{COPD}_{\mathrm{L}}$ and $(60.5 \pm 7.6$ years $)$ $\mathrm{COPD}_{\mathrm{N}}$. Both COPD groups showed less years of smoking cessation than controls (23.2 \pm 5.5 years) (ANOVA $\mathrm{P}<0.01)$.

Compared to $\mathrm{C}, \mathrm{COPD}_{\mathrm{N}}$ had lower $\mathrm{BMI}$ and physical activity and $\mathrm{COPD}_{\mathrm{L}}$ had very different anthropometric characteristics.

Compared to $\mathrm{COPD}_{\mathrm{N}}, \mathrm{COPD}_{\mathrm{L}}$ had significantly lower BMI, FFM and FFMI, poorer HRQoL with higher values in all of the domains of the St. George's respiratory questionnaire, higher mMRC score and worse muscle function as assessed by QMVC. They also had lower levels of physical activity measured by the Voorrips questionnaire $\left(\mathrm{PA}_{\mathrm{V}}\right)$ but no difference were seen in activities of daily living (ADL) assessed with the LCADL $\left(\mathrm{PA}_{\mathrm{L}}\right)$, specifically designed to assess ADL in patients with COPD (Table 1).

Both COPD groups showed a redistribution of muscle fibre type with a higher proportion of type II fibres and a lower proportion type I in comparison to healthy controls. Type II fibre area was significantly reduced in $\mathrm{COPD}_{\mathrm{L}}$ in comparison with $\mathrm{COPD}_{\mathrm{N}}$ (Table 1).

In the whole COPD population FFMI correlated with $\mathrm{FEV}_{1}(\mathrm{r}=0.51, \mathrm{p}<0.05), \mathrm{mMRC}$ dyspnoea score (rho $=-0.48, \mathrm{p}<0.05)$, QMVC $(\mathrm{r}=0.76, \mathrm{p}<0.001)$, and 
physical activity $\left(\mathrm{PA}_{\mathrm{V}}\right)(\mathrm{r}=0.61, \mathrm{p}<0.01)$ while skeletal muscle function (QMVC) correlated with FFMI ( $\mathrm{r}=0.76$, $\mathrm{p}<0.0001$ ), exacerbation rate (rho $=-0.57, \mathrm{p}<0.05)$, $6 \mathrm{MWD}(\mathrm{r}=0.62, \mathrm{p}<0.01)$, physical activity $\left(\mathrm{PA}_{\mathrm{V}}\right)(\mathrm{r}=0.53$, $\mathrm{p}<0.05)$ and BODE index (rho $=-0.66, \mathrm{p}<0.05)$.

\section{Global assessment of gene expression}

Hierarchical and k-means clustering were undertaken with normalized data. No pattern emerged from this analysis. We therefore performed three pair-wise class comparisons: $\mathrm{COPD}_{\mathrm{L}}$ vs. $\mathrm{COPD}_{\mathrm{N}}, \mathrm{COPD}_{\mathrm{L}}$ vs. $\mathrm{C}$ and $\mathrm{COPD}_{\mathrm{N}}$ vs. $\mathrm{C}$, employing Rank Products (RP) to detect differentially expressed genes (DEGs). First, a list of upor down-regulated genes for each comparison was selected based on a PFP $<0.05$ (Table 2) (no FC criterion was applied). Comparisons of both groups COPD patients with $\mathrm{C}$ showed the most differentially expressed genes and the comparison between the COPD groups the least.

In order to select the most relevant DEGs related to muscle wasting in COPD, we selected a list of DEGs between $\mathrm{COPD}_{\mathrm{L}}$ and $\mathrm{COPD}_{\mathrm{N}}$. Furthermore, among this list, we selected those genes that were also differentially expressed between $\mathrm{COPD}_{\mathrm{L}}$ and $\mathrm{C}$ (Figure 1). This list of 1110 DEGs (1763 probes) (454 DEGs up-regulated and 656 DEGs down-regulated) was used to conduct a functional enrichment analysis. Table 3 displays the most characteristic GO biological processes (with 8 or more genes representing each class/category/pathway) that were enriched in this list. Significant GO classes from the list of up-regulated DEG correspond to functional terms related to protein synthesis, muscle organ development and striated muscle contraction while functional terms related to glucose metabolism, energy production, striated muscle development and striated muscle contraction were identified from the list of down-regulated genes.

Since some of these DEGs displayed marginal changes in gene expression, we applied a more restrictive criterion, namely a fold change cutoff of $1.5(1.5 \geq \mathrm{FC} \geq 1.5)$ in order to select more robust genes. Figure 2 shows the list of DEGs generated between $\mathrm{COPD}_{\mathrm{L}}$ and both other groups of subjects with normal muscle mass using this criterion. When the combined criteria of both statistical

Table 2 DEGs between $\operatorname{COPD}_{\mathrm{L}}, \mathrm{COPD}_{\mathrm{N}}$ and $\mathrm{C}$

\begin{tabular}{llccc}
\hline & \multicolumn{1}{c}{ COPD $_{\mathbf{L}}$ vs COPD $_{\mathbf{N}}$} & COPD $_{\mathbf{L}}$ vs $C$ & COPD $_{\mathbf{N}}$ vs C \\
\hline Up regulated & Probes & 954 & 1352 & 1050 \\
& Genes & 531 & 830 & 724 \\
Down & Probes & 1054 & 1631 & 1201 \\
regulated & Genes & 748 & 1152 & 799 \\
\hline
\end{tabular}

DEGs between $C O P D_{L}$ vs. $C O P D_{N}, C O P D_{L}$ vs. $C$ and $C O P D_{N}$ vs $C$. Number of up and down regulated probes and genes with a PFP $<0.05$ in all three comparisons. significance and fold change were applied the numbers of DEGs were notably reduced. Eighty three probes, representing 64 DEGs, were identified between $\mathrm{COPD}_{\mathrm{L}}$ and $\mathrm{COPD}_{\mathrm{N}}$. Fifty six of these probes, representing 42 DEGs, were also differentially expressed between $\mathrm{COPD}_{\mathrm{L}}$ and $\mathrm{C}$ (Table 4 and 5 ). These 42 DEGs were selected for further analysis. Although this shorter list of genes was not suitable for a functional enrichment analysis, the biological significance of these genes was related with the significant functional categories identified in the list of 1110 DEGs originally obtained with a $\mathrm{PFP}<0.05$. Among the up-regulated genes (Table 4) from this list of 42 DEGs, we have identified genes related to cell cycle inhibition and inhibition of cell growth (CDKN1A, GADD45A, PMP22, BEX2, CGREF1, CYR61), inhibition of sarcomeric organization (HDGF), stress inducible factor (ATF3), inhibition of glucose metabolism (PDK4), lipid metabolism (LPL), aminoacid transportation (SLC22A3, SLC38A1), muscle repair (ABRA) and myogenesis (NNMT, ANKRD1). Among the down-regulated genes (Table 5) we have identified genes related to fatty acid synthesis (MCAT), muscle formation (CHRDL2, IRX4, PMEPA1), glucose endocytosis (RAB10) and gluconeogenesis (GPT).

\section{Relationship with muscle structure and function}

In order to identify bona fide muscle wasting associated genes we selected, from this subset of 42 DEGs, those that correlated with FFMI in the whole population including the healthy control. Ten out of twenty six of the upregulated DEGs were negatively correlated with FFMI while nine out of the sixteen down-regulated DEGs were positively correlated with FFMI (Table 6).

Since $\mathrm{COPD}_{\mathrm{L}}$ were characterized by type II fibre atrophy in comparison with $\mathrm{COPD}_{\mathrm{N}}$, we explored the correlations between these DEGs and type II fibre area. Three of the up-regulated DEGs (PMP22, CGREF1 and LPL) were negatively correlated with type II fibre area while four of the down-regulated DEGs (SAA1, CHRLD2, and FARP1) were positively correlated with type II fibre area (Additional file 3: Table S1). In turn, several of the up-regulated (ANKRD1, CDKN1A, GADD45A, ATF3, RAB15, ABRA and SLC22A3) and down-regulated (EVX1, PMEPA1, GPT, RAB10, SPSB1) DEGs in $\mathrm{COPD}_{\mathrm{L}}$ correlate with the proportion of Type II fibres (Additional file 4: Table S2). Moreover several upregulated (negatively) and down-regulated (positively) DEGs correlated with QMVC, a measurement of muscle function (Additional file 5: Table S3).

\section{qPCR validation}

Eleven genes (CDKN1A, CEBPA, CYR61, EFCAB7, EGR1, HMOX1, PDE11A, SAA1, SLC22A3, SLC38A1 and SLC43A2) were selected for $\mathrm{qPCR}$ validation of the 


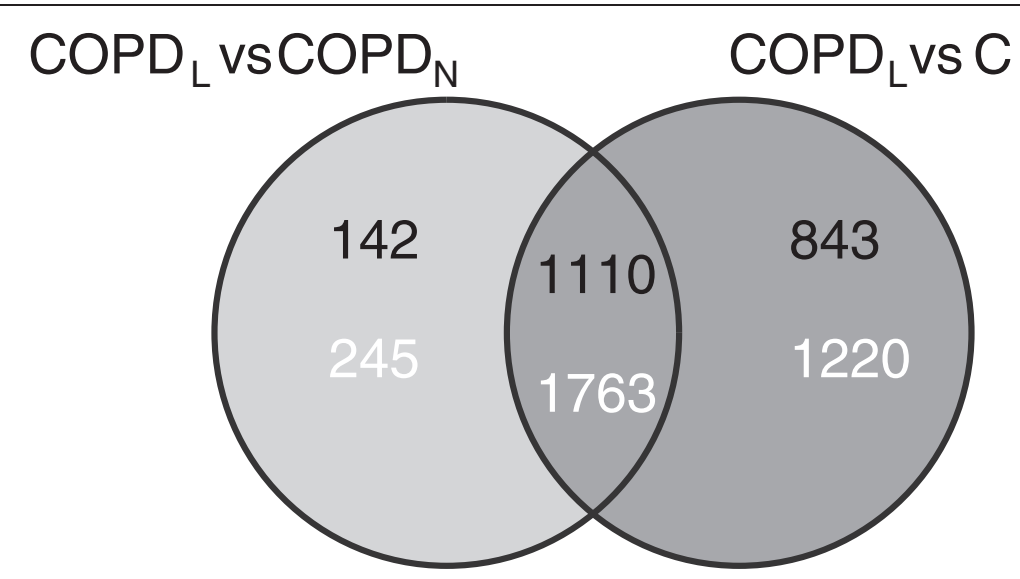

Figure 1 Venn diagram showing the numbers of genes (black) and probes (white) differentially expressed between COPD $\mathrm{L}_{\mathrm{L}}$ and both other groups without muscle wasting $\left(\mathrm{COPD}_{\mathrm{N}}\right.$ and $\left.\mathrm{C}\right)(\mathrm{PFP}<0.05)$.

microarray experiment based on either a microarrayderived fold-change $(>2)$ or statistical significance for differential expression and/or the biological relevance for the different comparisons $\left(\mathrm{COPD}_{\mathrm{N}}\right.$ vs $\mathrm{COPD}_{\mathrm{L}}, \mathrm{COPD}_{\mathrm{N}}$ vs $\mathrm{C}$ and $\mathrm{COPD}_{\mathrm{L}}$ vs $\mathrm{C}$ ) (Figure $3 \mathrm{~A}$ and Additional file 6: Figure S2). As shown in Table 7, the altered expression of all these genes was confirmed by real time TaqMan PCR.

Figure 3A shows qPCR data for CDKN1A, one of the six genes representing the group of genes related to cell cycle inhibition and inhibition of cell growth from the list of 42 DEGs identified between $\mathrm{COPD}_{\mathrm{L}}$ and both other groups of subjects with normal muscle mass. CDKN1A mRNA expression was increased in $\mathrm{COPD}_{\mathrm{L}}$ compared to both $\mathrm{COPD}_{\mathrm{N}}$ and $\mathrm{C}(\mathrm{p}<0.005)$ (Graphics for the remaining eight genes are depicted in the Additional file 6: Figure S2). The expression of several of these genes assessed by qPCR correlated with parameters of muscle structure and function. CDKN1A and ANKRD1 correlated with percentage of Type II fibres (Figure 4), CEBPA, CYR61, EFCAB7, SLC22A3 and SLC38A1 correlated negatively with FFMI (Figure 5). In turn, CEBPA correlated positively $($ rho $=0.45, \mathrm{p}<0.05)$ while SLC43A2 correlated negatively ( rho $=-0.65, \mathrm{p}<$ $0.0005)$ with the proportion of Type II fibres. Moreover, CDKN1A, CYR61, CEBPA, EFCAB7, SLC22A3 correlated negatively with QMVC, a measurement of muscle function (Additional file 7: Figure S3).

\section{Immunobloting}

As CDKN1A was differentially expressed between $\mathrm{COPD}_{\mathrm{L}}$ and $\mathrm{COPD}_{\mathrm{N}}$ but also between $\mathrm{COPD}_{\mathrm{L}}$ and $\mathrm{C}$, with a fold change over 1.5 , and it also correlated with several measurements of skeletal muscle structure and function

Table 3 GO Terms associated with relevant genes related to muscle wasting

\begin{tabular}{|c|c|c|c|c|}
\hline Source & GO terms & Fold enrichment & $\mathrm{N}^{\circ}$ of gene in the term & FDR \\
\hline \multirow{6}{*}{ Up-regulated genes } & Traslational initiation & 7.9 & 11 & 0.001 \\
\hline & Traslational elongation & 14.7 & 49 & $6.05 E-42$ \\
\hline & Ribosomal biogenesis & 4.2 & 17 & 0.004 \\
\hline & rRNA processing & 4.9 & 15 & 0.002 \\
\hline & Muscle organ development & 3.2 & 20 & $1.62 \mathrm{E}-05$ \\
\hline & Striated muscle contraction & 6.5 & 10 & 1.55E-05 \\
\hline \multirow{6}{*}{ Down-regulated genes } & Glucose metabolic process & 3.3 & 21 & 0.008 \\
\hline & Energy derivation by oxidation of organic compounds & 5.8 & 37 & 4.86E-15 \\
\hline & Electron transport chain & 6.2 & 31 & 5.77E-13 \\
\hline & ATP synthesis coupled electron transport & 9.3 & 22 & $1.91 \mathrm{E}-12$ \\
\hline & Striated muscle tissue development & 3.4 & 18 & 0.02 \\
\hline & Muscle contraction & 4.7 & 31 & $1.94 \mathrm{E}-09$ \\
\hline
\end{tabular}

GO Terms associated with DEGs between $\operatorname{COPD}_{\mathrm{L}}$ vs. $\mathrm{COPD}_{\mathrm{N}}$ and $\mathrm{COPD}_{\mathrm{L}}$ vs. $\mathrm{C}$.

Functional enrichment analysis of 454 up-regulated and 656 down-regulated $D E G$ s between $C O P D_{L}$ vs. $C O P D_{N}$ and $C O P D_{L}$ vs. $C(F D R<0.05)$ with the corresponding $G O$ term, the fold enrichment, number of genes involved in the term and the FDR (False discovery Rate). 


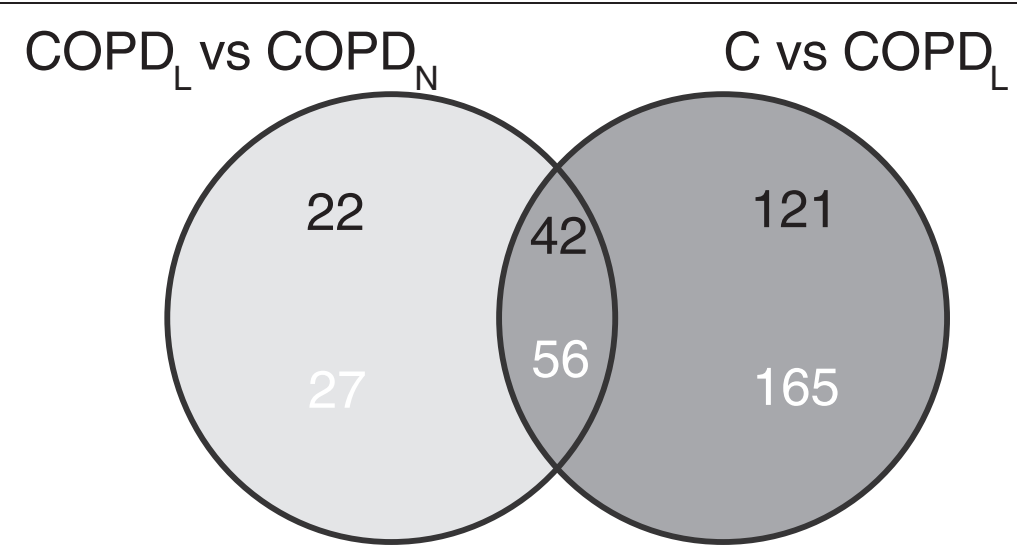

Figure 2 Venn diagram showing the numbers of genes (black) and probes (white) differentially expressed between COPD $\mathrm{L}_{\mathrm{L}}$ and both other groups without muscle wasting (COPD and $C)$ (PFP $<0.05 ;-1.5 \geq F C \geq 1.5)$.

and is consistently overexpressed in other conditions characterised by muscle wasting, we chose to explore the protein levels of p21 in our samples by immunoblotting. This showed that $\mathrm{p} 21$ is over expressed in $\mathrm{COPD}_{\mathrm{L}}$ in comparison to both $\mathrm{COPD}_{\mathrm{N}}$ and $\mathrm{C}$ (Figure $3 \mathrm{~B}$ ). However, only the comparison between $\mathrm{COPD}_{\mathrm{L}}$ and $\mathrm{COPD}_{\mathrm{N}}$ was statistically significant.

\section{Discussion}

This study shows relevant changes in gene expression in the vastus lateralis of COPD patients with skeletal muscle wasting. We identified several up-regulated genes associated with cell cycle arrest and growth regulation, and down-regulated genes associated with muscle formation and glucose metabolism in patients with low FFMI. These DEGs correlated with several parameters of muscle structure and function. The altered expression of 11 genes was confirmed by qPCR and the increased level in $\mathrm{COPD}_{\mathrm{L}}$ of $\mathrm{P} 21$, the protein encoded by $\mathrm{CDKN} 1 \mathrm{~A}$, was also corroborated by immunoblotting.

Our initial approach revealed extensive changes in gene expression that allowed us to identify several biologically relevant GO terms related to protein synthesis, muscle contraction and muscle organ development (from the upregulated list of genes in $\mathrm{COPD}_{\mathrm{L}}$ ) and oxidative energy production, glucose metabolism and striated muscle contraction and myogenesis (from the down-regulated list of genes in $\left.\mathrm{COPD}_{\mathrm{L}}\right)$. The concomitant activation and deregulation of different genes involved in myogenesis reveal the complex nature of the muscle wasting process in this population of patients. This, together with the activation of genes related to protein synthesis, show a potentially adaptive, yet clearly ineffective, response at maintaining muscle mass [37].

Using a more restrictive approach we were able to discard genes with potential marginal changes and identify a subset of more substantial DEGs. This group of
DEGs fulfil several criteria: a) they were differentially expressed between $\mathrm{COPD}_{\mathrm{L}}$ and $\mathrm{COPD}_{\mathrm{N}}$, b) showed a fold change $\geq 1.5$ or $\leq 1.5$ between $\mathrm{COPD}_{\mathrm{L}}$ and $\mathrm{COPD}_{\mathrm{N}}, \mathrm{c}$ ) were also differentially expressed between $\mathrm{COPD}_{\mathrm{L}}$ and $\mathrm{C}, \mathrm{b}$ ) showed a fold change $\geq 1.5$ or $\leq 1.5$ between $\mathrm{COPD}_{\mathrm{L}}$ and $C$. These criteria markedly reduced the list of DEGs but reinforced the relevance of these genes for the process of muscle wasting. This approach identified up-regulated DEGs related to the inhibition of cell growth and cell cycle and down-regulated genes related to myogenesis and glucose metabolism in $\operatorname{COPD}_{\mathrm{L}}$. Several of these DEGs correlate with FFMI, parameters of muscle structure and function such as type II fibre size (the fibres showing atrophy in $\mathrm{COPD}_{\mathrm{L}}$ ), the proportion of type II fibres and QMVC, indicating a potential role of these genes in the muscle wasting process.

Among these DEGs, GADD45A is induced by DNA damage [38] and stress (such as fasting or immobilization) $[39,40]$. GADD45A represses genes involved in anabolic signalling and energy production and induces pro-atrophy genes $[39,40]$. Interestingly, genes related to energy production by oxidation and glucose metabolic processes were down-regulated in our population of $\mathrm{COPD}_{\mathrm{L}}$. GADD45A [41] and CDKN1A [42-44] have previously been identified in several conditions associated with muscle atrophy. Moreover, myostatin suppresses muscle cell growth via the transcriptional regulation of CDKN1A [45]. p21, the protein encoded by this gene, can inhibit apoptosis (when present in the cytosol by arresting the cell cycle allowing for DNA repair) or promote apoptosis (in the nucleus and interacting with other proteins) $[38,46,47]$. The interaction between p21 and growth arrest and DNA damage-inducible genes such as GADD45A results in apoptosis [38]. Furthermore, CDKN1A and GADD45A are also related to other muscular disorders such as amyotrophic lateral sclerosis [43]. ATF3, another of the DEGs up-regulated in $\mathrm{COPD}_{\mathrm{L}}$, together with GADD45A and 
Table 4 Up-regulated DEGs between $\mathrm{COPD}_{\mathrm{L}}$ vs. $\mathrm{COPD}_{\mathrm{N}}$ and $C O P D_{L}$ vs. $C$ with a FC over $\mathbf{1 . 5}$

\begin{tabular}{|c|c|c|c|c|c|}
\hline \multirow[t]{2}{*}{ PROBE } & \multirow[t]{2}{*}{ Gene symbol } & \multicolumn{2}{|c|}{$\mathrm{COPD}_{\mathrm{L}}$ vs. $\mathrm{COPD}_{\mathrm{N}}$} & \multicolumn{2}{|c|}{ COPD $_{\mathrm{L}}$ vs. $\mathrm{C}$} \\
\hline & & PFP & FC & PFP & FC \\
\hline A_32_P200144 & IGHG1 & 0.044 & 5.3 & 0.0177 & 9.4 \\
\hline A_23_P43979 & IGLL5 & 0.0435 & 5.1 & 0.0133 & 7.9 \\
\hline A_24_P104980 & IGLL5 & 0.0252 & 4.3 & 0.0098 & 6.5 \\
\hline A_23_P398566 & & 0.0133 & 2.9 & 0.0491 & 1.7 \\
\hline A_23_P46429 & CYR61 & 0 & 2.8 & 0 & 2.9 \\
\hline A_24_P370946 & CYR61 & 0.0009 & 2.7 & 0.0013 & 2.7 \\
\hline A_23_P46426 & CYR61 & 0.0008 & 2.5 & 0.0005 & 2.6 \\
\hline A_23_P161218 & ANKRD1 & 0.0074 & 2.5 & 0.0067 & 1.9 \\
\hline A_24_P376707 & HDGF & 0.0402 & 2.5 & 0.0169 & 2.6 \\
\hline A_23_P19733 & SLC22A3 & 0.0004 & 2.4 & 0 & 4.6 \\
\hline A_23_P34915 & ATF3 & 0.0062 & 2.1 & 0.0011 & 3.4 \\
\hline A_32_P60459 & OTUD1 & 0 & 2.0 & 0 & 2.6 \\
\hline A_32_P219135 & & 0.012 & 2.0 & 0.0042 & 2.4 \\
\hline A_23_P166248 & RCAN1 & 0.0162 & 1.9 & 0.0417 & 1.6 \\
\hline A_23_P22735 & BEX2 & 0.0085 & 1.9 & 0.0003 & 3.2 \\
\hline A_23_P127584 & NNMT & 0 & 1.9 & 0 & 3.0 \\
\hline A_23_P100711 & PMP22 & 0 & 1.8 & 0 & 2.2 \\
\hline A_23_P49338 & TNFRSF12A & 0.0022 & 1.8 & 0.0019 & 1.8 \\
\hline A_23_P363399 & SLC38A1 & 0.0257 & 1.8 & 0.0027 & 3.0 \\
\hline A_23_P146233 & LPL & 0.0003 & 1.8 & 0.0022 & 1.5 \\
\hline A_24_P243749 & PDK4 & 0 & 1.7 & 0 & 1.6 \\
\hline A_23_P403445 & CGREF1 & 0.0353 & 1.7 & 0.0446 & 1.6 \\
\hline A_24_P193295 & RAB15 & 0.0004 & 1.7 & 0.0002 & 1.9 \\
\hline A_23_P208540 & LOC644482 & 0.0095 & 1.7 & 0.0026 & 1.8 \\
\hline A_24_P261734 & SLC38A1 & 0.0148 & 1.7 & 0.0012 & 2.9 \\
\hline A_23_P408095 & DSTN & 0.0091 & 1.6 & 0.033 & 1.6 \\
\hline A_23_P418031 & & 0.0133 & 1.6 & 0.0169 & 1.7 \\
\hline A_23_P314024 & HLA-F & 0.0075 & 1.6 & 0.0026 & 1.8 \\
\hline A_23_P166109 & FLRT3 & 0.0419 & 1.6 & 0.0145 & 1.8 \\
\hline A_23_P59210 & CDKN1A & 0.0074 & 1.5 & 0.0014 & 2.2 \\
\hline A_23_P23221 & GADD45A & 0.0055 & 1.5 & 0.0016 & 1.7 \\
\hline A_32_P234459 & HLA-H & 0.0206 & 1.5 & 0.0103 & 1.7 \\
\hline A_23_P350295 & & 0.0009 & 1.5 & 0.0003 & 1.7 \\
\hline A_24_P50489 & & 0.0024 & 1.5 & 0.0008 & 1.5 \\
\hline A_23_P125109 & & 0.0036 & 1.5 & 0.0002 & 1.7 \\
\hline A_23_P313482 & ABRA & 0.0003 & 1.5 & 0.0002 & 1.5 \\
\hline
\end{tabular}

All probes are differentially expressed with a PFP (percentage of false positive) $<0.05$ and a FC (fold change); $-1.5 \geq F C \geq 1.5$.

CDKN1A, is also associated with cell cycle arrest in response to DNA damage [48]. ATF3 is induced by stress and is related to cardiac contractility abnormalities [49] and muscular disorders such as amyotrophic lateral sclerosis [43]. ATF3 gene expression correlated negatively with FFMI
Table 5 Down-regulated DEGs between $\operatorname{COPD}_{\mathrm{L}}$ vs. $\mathrm{COPD}_{\mathrm{N}}$ and $C O P D_{L}$ vs. $C$ with a FC over 1.5

\begin{tabular}{|c|c|c|c|c|c|}
\hline \multirow[t]{2}{*}{ PROBE } & \multirow[t]{2}{*}{ Gene symbol } & \multicolumn{2}{|c|}{$\mathrm{COPD}_{\mathrm{L}}$ vs. $\mathrm{COPD}_{\mathrm{N}}$} & \multicolumn{2}{|c|}{ COPD $_{\mathrm{L}}$ vs. $\mathrm{C}$} \\
\hline & & PFP & $\mathrm{FC}$ & PFP & $\mathrm{FC}$ \\
\hline A_24_P401294 & FLJ35934 & 0 & -1.5 & 0 & -1.5 \\
\hline A_24_P96961 & SPSB1 & 0.0076 & -1.5 & 0.0004 & -2.2 \\
\hline A_24_P576591 & & 0.0206 & -1.5 & 0.0096 & -1.5 \\
\hline A_24_P319675 & RAB10 & 0.0105 & -1.5 & 0 & -2.8 \\
\hline A_23_P57089 & PMEPA1 & 0.0056 & -1.5 & 0.0005 & -1.8 \\
\hline A_23_P146339 & GPT & 0.0013 & -1.6 & 0.0007 & -1.6 \\
\hline A_23_P308763 & FARP1 & 0.0047 & -1.6 & 0.0018 & -1.7 \\
\hline A_24_P419028 & MOP-1 & 0.0124 & -1.6 & 0.0013 & -1.8 \\
\hline A_23_P37856 & HBA2 & 0.0003 & -1.6 & 0 & -2.4 \\
\hline A_23_P205355 & SERPINA5 & 0.0377 & -1.7 & 0.0031 & -2.2 \\
\hline A_24_P413126 & PMEPA1 & 0.0064 & -1.7 & 0.0006 & -1.9 \\
\hline A_24_P368943 & EVX1 & 0.0006 & -1.7 & 0.0002 & -1.7 \\
\hline A_23_P26457 & HBA2 & 0.0005 & -1.8 & 0 & -2.5 \\
\hline A_32_P163891 & & 0.0344 & -1.8 & 0.0104 & -2.4 \\
\hline A_24_P75190 & HBD & 0.0003 & -1.9 & 0 & -3.1 \\
\hline A_24_P20795 & IRX4 & 0.0055 & -1.9 & 0.005 & -1.9 \\
\hline A_23_P13548 & CHRDL2 & 0.0139 & -2.0 & 0.0452 & -1.6 \\
\hline A_24_P412734 & PRSS36 & 0.0474 & -2.3 & 0.0039 & -1.9 \\
\hline A_24_P237328 & MCAT & 0.0483 & -2.4 & 0.0123 & -1.8 \\
\hline A_24_P335092 & SAA1 & 0.0207 & -2.6 & 0.0003 & 3.8 \\
\hline
\end{tabular}

All probes are differentially expressed with a PFP (percentage of false positive) $<0.05$ and a FC (fold change) $-1.5 \geq F C \geq 1.5$.

and QMVC in our population. Another gene up-regulated in $\mathrm{COPD}_{\mathrm{L}}, \mathrm{ANKRD1}$, has been associated with upregulation of $\mathrm{p} 21$, one of its downstream targets [50]. ANKRD1 is expressed in the muscle and migrates to the nucleus when the muscle is under stress. It has been shown to be up-regulated during muscle atrophy [51]. Evidence suggests that ANKRD1 per se cannot initiate atrophy. However, the observation that p21 is increased whenever ANDRD1 is increased in different models of muscle atrophy highlights the importance of this interaction in the muscle wasting process [50]. Moreover, a switch towards fast-twitch fibres has been reported in models of atrophy in association with up-regulation of ANKRD1 [50]. It is of note that ANKRD1 expression was negatively correlated with FFMI and QMVC and positively correlated with the proportion of Type II fibres in our $\mathrm{COPD}_{\mathrm{L}}$, as were CDKN1A, GADD45A1 and ATF3. GADD45A1 also correlated negatively with muscle function measured as QMVC. CDKN1A has also been shown to interact with CEBPA [46] leading to cell arrest [38], and was up-regulated in $\mathrm{COPD}_{\mathrm{L}}$ and confirmed by qPCR. In fact, CEBPA inhibits cell proliferation by stabilising p21 [52] and protecting against its degradation [53]. CEBPA and CDKN1A gene expression assessed by qPCR correlated negatively with 
Table 6 DEGs between $\operatorname{COPD}_{\mathrm{L}}$ and both $\operatorname{COPD}_{\mathrm{N}}$ and $\mathrm{C}$ that that varied with percentage of FFMI

\begin{tabular}{|c|c|c|c|c|}
\hline Source & Probe & Gene symbol & rho & $\mathbf{p}$ \\
\hline \multirow{14}{*}{ Up-regulated genes } & A_23_P22735 & BEX2 & -0.55 & 0.0019 \\
\hline & A_23_P100711 & PMP22 & -0.48 & 0.0085 \\
\hline & A_23_P166109 & FLRT3 & -0.4 & 0.0327 \\
\hline & A_24_P193295 & RAB15 & -0.44 & 0.0167 \\
\hline & A_23_P46426 & CYR61 & -0.38 & 0.0391 \\
\hline & A_24_P370946 & CYR61 & -0.39 & 0.0358 \\
\hline & A_23_P46429 & CYR61 & -0.39 & 0.0337 \\
\hline & A_24_P261734 & SLC38A1 & -0.47 & 0.0098 \\
\hline & A_23_P363399 & SLC38A1 & -0.47 & 0.01 \\
\hline & A_23_P19733 & SLC22A3 & -0.55 & 0.002 \\
\hline & A_23_P49338 & TNFRSF12A & -0.36 & 0.05 \\
\hline & A_32_P219135 & & -0.45 & 0.015 \\
\hline & A_23_P34915 & ATF3 & -0.36 & 0.055 \\
\hline & A_23_P161218 & ANKRD1 & -0.47 & 0.0099 \\
\hline \multirow{10}{*}{ Down-regulated genes } & A_23_P13548 & CHRDL2 & 0.44 & 0.017 \\
\hline & A_24_P20795 & IRX4 & 0.36 & 0.056 \\
\hline & A_24_P368943 & EVX1 & 0.36 & 0.057 \\
\hline & A_24_P413126 & PMEPA1 & 0.52 & 0.0034 \\
\hline & A_23_P57089 & PMEPA1 & 0.57 & 0.0012 \\
\hline & A_23_P205355 & SERPINA5 & 0.5 & 0.0054 \\
\hline & A_24_P419028 & MOP-1 & 0.37 & 0.045 \\
\hline & A_23_P146339 & GPT & 0.36 & 0.054 \\
\hline & A_24_P319675 & RAB10 & 0.64 & 0.0002 \\
\hline & A_24_P401294 & FLJ35934 & 0.44 & 0.0157 \\
\hline
\end{tabular}

Significant associations between up-regulated and down-regulated DEGs and FFMI. rho: spearman correlation index.

FFMI and QMVC in our population. The simultaneous up-regulation of these genes in $\mathrm{COPD}_{\mathrm{L}}$ together with the strong association with FFMI, and parameters of skeletal muscle structure and function suggest that cell cycle arrest followed by apoptosis play a role in the process of muscle wasting in this population in response to stress. The presence of muscle cell apoptosis in peripheral muscle of patients with COPD is still controversial. Some groups have reported increased cell apoptosis, assessed as DNA fragmentation [54,55], whereas others failed to report apoptosis, assessed as active caspase-3 [56]. It is interesting that, as mentioned previously, p21 has a dual function and can promote or inhibit apoptosis [38,46,47]. Apoptosis induced by $\mathrm{p} 21$ is distinct from that induced by other proapoptotic agents and does not involve activation of caspases [38]. In fact, while the carboxyl terminus interacts with molecules such as GADD45A or CEBPA, the Nterminus can interact with procaspase- 3 to block activation of caspase-3 [57]. Hence, apoptosis induced by p21 is not affected by caspase inhibitors [38]. This may explain

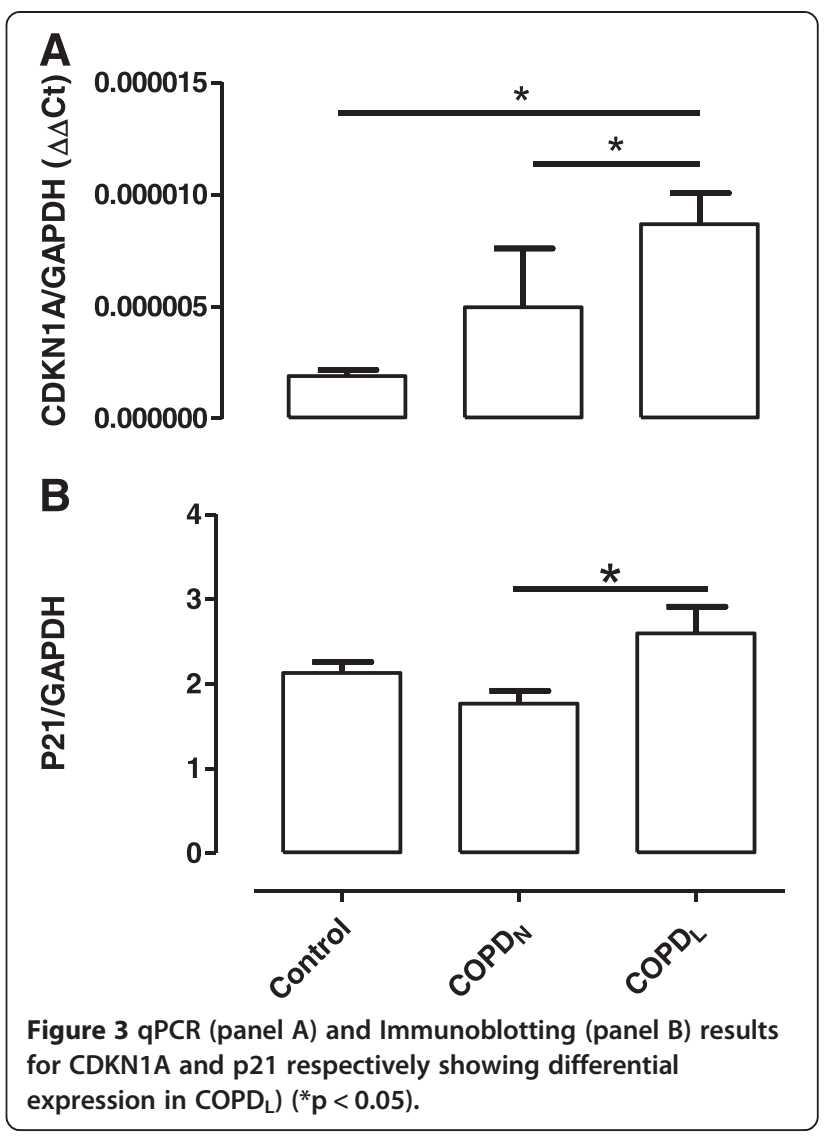

the controversy in the literature regarding muscle cell apoptosis in peripheral muscle of patients with COPD.

Other genes known to be overexpressed under stress situations and inflammation were also up-regulated in $\mathrm{COPD}_{\mathrm{L}}$, such as CYR61 whose expression increases with exercise in humans [58-60]. CYR61 is required for the migration of myoblasts during the regeneration process [61] and mediates angiogenesis [60,62]. On the other hand, CY61 is increased in the muscle in models of malnutrition [63] and muscle denervation [64] and promotes cell migration and immobilise inflammatory cells in the site of inflammation and tissue repair [65]. Moreover, CYR61 gene expression assessed by both, microarray and $\mathrm{qPCR}$, correlated negatively with FFM and QMVC in our population. In line with these findings, oxidative stress has been consistently shown in limb muscle of patients with COPD [66], particularly in patients with muscle wasting [67]. While local muscle oxidative stress is induced by exercise [67], the exerciseinduced increase in antioxidant enzymes is attenuated or inhibited in the muscle of underweight patients with COPD $[68,69]$. HMOX1, a gene involved in the response to oxidants known to protect against cytotoxicity of oxidative stress and nitric oxide metabolism, was downregulated in our population of COPD [70]. In turn, although not consistently shown, some authors have 


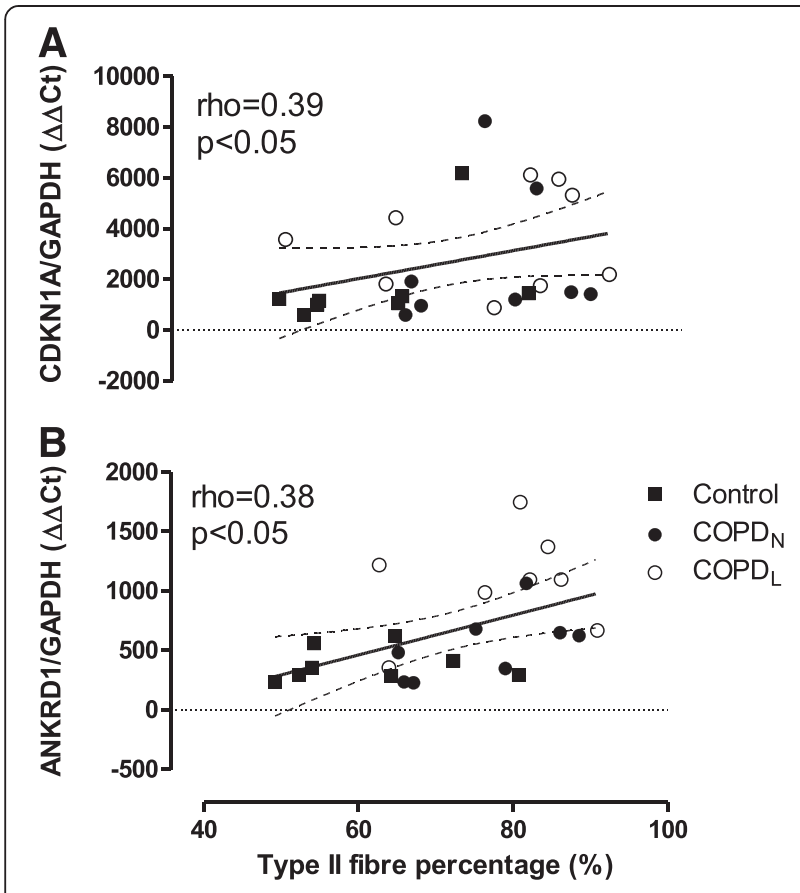

Figure 4 Correlations between percentage of Type II fibres ( $x$ axis) and $q P C R$ gene expression (corrected by GAPDH housekeeping gene $(\Delta \Delta \mathrm{Ct}) \mathrm{CDKN1A}$ panel $\mathrm{A}$; ANKRD1 panel $\mathrm{B})$ in $\operatorname{COPD}_{\mathrm{L}}(\mathbf{o}), \mathrm{COPD}_{\mathrm{N}}(\bullet)$ and $\mathrm{C}(\boldsymbol{\square})$ (y axis). Solid line represents regression line and dashed lines $95 \% \mathrm{Cl}$.

demonstrated an increase in local inflammation in the muscle of patients with COPD [71-73]. Regardless of the presence of inflammatory markers, activation of nuclear factor $\mathrm{kB}(\mathrm{NFkB})$ in peripheral muscle of patients with COPD suggests an increased inflammatory state [66,74-76]. TNFRS12A, a direct kB target, also known as

Table 7 qPCR Validation of microarray experiment

\begin{tabular}{|c|c|c|}
\hline Gene symbol & Microarray selection criteria & qPCR result \\
\hline CDKN1A & PFP $<0.005$, FC 2.19 COPD $_{L}$ VS C & $p<0.005$ \\
\hline CEBPA & PFP $<0.005$, FC $2.08 C_{C O P D_{L}}$ vS $C$ & $p<0.005$ \\
\hline CYR61 & PFP $<0.005, F C 2.6 C_{\text {COPD }}$ Vs $C$ & $p<0.005$ \\
\hline EFCAB7 & PFP $<0.005$, FC $2.63 \mathrm{COPD}_{\mathrm{L}}$ vs $C$ & $p<0.005$ \\
\hline EGR1 & PFP $<0.005, F C-2.11 \mathrm{COPD}_{N}$ vs $C$ & $\mathrm{p}<0.05$ \\
\hline \multirow[t]{2}{*}{ HMOX1 } & PFP $<0.005, F C-2.31 C_{C O P D}$ vS $C$ & $p=0.06$ \\
\hline & PFP $<0.005, F C-2.26 \mathrm{COPD}_{N}$ vs $C$ & $p<0.05$ \\
\hline PDE11 & PFP $<0.005, F C-2.28 C_{C O P D_{L}}$ vs $C$ & $p<0.05$ \\
\hline \multirow[t]{2}{*}{ SAA1 } & PFP <0.005, FC 3.8 COPD $_{\mathrm{L}}$ vs C & $p<0.005$ \\
\hline & PFP $<0.005$, FC $10.1 \mathrm{COPD}_{N}$ vs $C$ & ns \\
\hline \multirow[t]{2}{*}{ SLC22A3 } & PFP $<0.005$, FC 2.46 COPD $_{L}$ vs $C C O P D_{N}$ & ns \\
\hline & PFP $<0.005$, FC 4.62 COPD $_{L}$ vs $C$ & $p<0.05$ \\
\hline SLC38A1 & PFP $<0.005$, FC 3.02 COPD $_{L}$ vs $C$ & $p<0.005$ \\
\hline SLC43A2 & PFP $<0.005, F C-2.1 C^{C O P D} L$ vS $C$ & $p<0.005$ \\
\hline
\end{tabular}

Comparative results of eleven selected genes for validation between microarrays and qPCR.
TWEAK, is known to induce muscle wasting in whole muscle [77] and required for denervation atrophy [78], an effect mediated by NFkB [51,77]. TNFRS12A was upregulated in $\mathrm{COPD}_{\mathrm{L}}$ and negatively correlated with FFMI and QMVC in our population.

The maintenance of skeletal muscle bulk results from the interaction of mechanisms leading muscle wasting (i.e. cell death, protein degradation) and muscle regeneration and protein synthesis. Several genes related to muscle development and regeneration (PMEPA1, IRX4, CHRDL2) were down-regulated in the $\mathrm{COPD}_{\mathrm{L}}[79,80]$. Some groups have investigated key markers of muscle regeneration in peripheral muscle of patients with COPD, although the evidence is unclear due to the lack of longitudinal data. Plant et al. (80) showed no differences in skeletal muscle expression of muscle-specific transcription factors associated with muscle differentiation Myf5, MyoD or myogenin. Crul et al. [81] showed no differences in MyoD in stable COPD patients. However, patients undergoing an exacerbation presented with reduced levels of MyoD compared to healthy controls (78). Thériault et al. have recently shown that besides greater number of attempts to regenerate the muscle, there was a profound reduction in the differentiation potential in COPD patients peripheral muscle [82]. Vogiatzis et al. (123) showed that exercise training increased the expression of MyoD in peripheral muscle of patents with COPD. Lewis et al. (124) showed an increment in IGF-I protein (an activator of cell growth and proliferation and an inhibitor of apoptosis) with exercise training and a combination of exercise training and testosterone together with an increment in myogenin mRNA expression. The role of impaired muscle regeneration, potentially in some circumstances (e.g. exacerbations), remains to be elucidated.

\section{Comparison with other studies}

We have identified other studies assessing peripheral muscle gene expression in COPD and other medical conditions associated with muscle cachexia, namely intensive care (ICU) patients [83] and cancer [84], as well as ageing-associated muscle wasting $[85,86]$ and studies exploring the effect of exercise training on gene expression in muscle of healthy subjects [87].

Despite differences in the populations and the methodology, which oblige to be cautious when comparing studies, we found interesting similarities with our results.

Two studies have explored gene expression in peripheral muscle of patients with COPD [88,89]. Debigaré [88] et al. compared vastus lateralis gene expression profiles from COPD patients with muscle atrophy and healthy controls. They have also found down regulation of genes involved in energy production and up-regulated genes related to cell cycle arrest including CDKN1A in the population of 


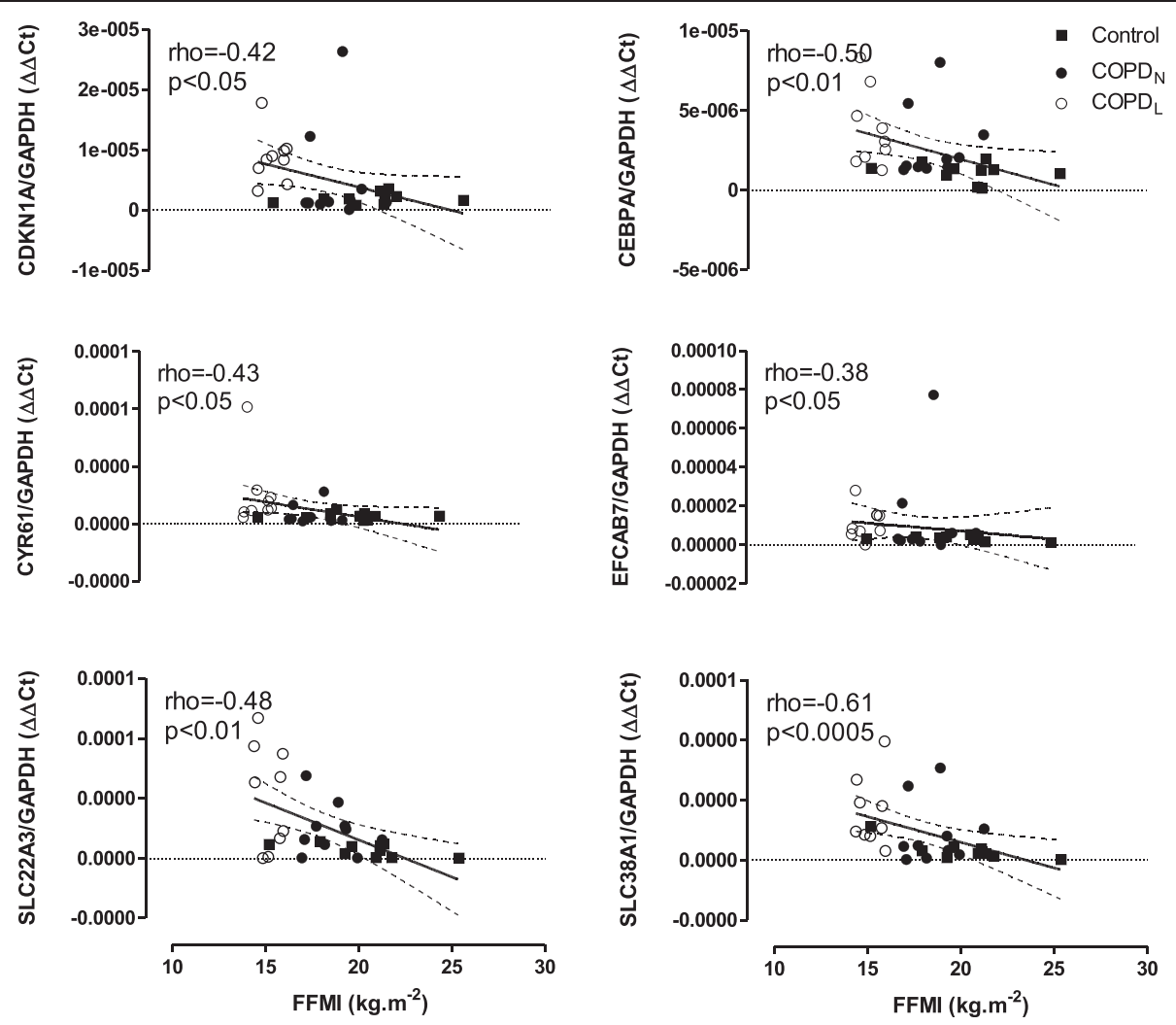

Figure 5 Correlations between FFMI ( $x$ axis) and qPCR gene expression corrected by GAPDH housekeeping gene $(\Delta \Delta C \mathrm{C})$ in $\mathrm{COPD}$ (o), $\operatorname{COPD}_{\mathbf{N}}(\bullet)$ and $\mathbf{C}(\boldsymbol{\square})$ (y axis). Solid line represents regression line and dashed lines $95 \% \mathrm{Cl}$.

patients with COPD and muscle wasting. In contrast, while several relevant genes from our study were also identified by other studies involving stable COPD patients [88] this was not the case in studies involving hospitalized patients [89], however, as in our study, pro-inflammatory genes, such as SAA, were identified in the exacerbated patients.

In addition, our results have similarities with other inflammatory medical conditions associated with muscle wasting, such as sepsis [83], and also in association with ageing $[85,86]$. Similarly to our population, genes encoding proteins involved in muscle metabolism are downregulated in association with ageing. Moreover, genes involved in cell cycle regulation and apoptosis are also affected by age. CDKN1A was up-regulated in the two mentioned studies in association with ageing. The similarities between our findings and studies exploring gene expression in ageing suggest that cell senescence may play a role as a pathogenic mechanism of muscle wasting in COPD. In fact, animal models of premature ageing show structural changes in the lungs and skeletal muscle that resemble those in COPD [90]. Shortening of telomeres, a marker of premature ageing, has been described in patients with COPD and muscle wasting [21].
Interestingly, as shown by Fredriksson et al. [83] in septic patients admitted to an intensive care unit (ICU), pro-inflammatory genes are up-regulated in the muscle of these patients including several genes found in our study. Moreover, they also found up-regulated genes related to cell cycle arrest including CDKN1A suggesting that that cell senescence could be also a mechanism leading to muscle wasting in this population. Moreover, inflammation and oxidative stress, a feature of patients with COPD and muscle wasting has been associated with stress-induced premature senescence [91].

Interestingly, when exploring the effects of exercise in skeletal muscle gene expression [86,87], while exercise training contribute to "normalise" the expression of genes related with energy production and oxidative capacity of the muscle, several genes found up-regulated in our COPD population were not modified ("normalized") by exercise training (including GADD45A, NNMT, ANKRD1, ATF3 and SLC38A1) suggesting that the increased expression of these genes in our population of $\mathrm{COPD}_{\mathrm{L}}$ is not related to physical activity levels since this should produce the opposite effect.

It is of note that the gene profile of patients with cancer [84] was not comparable to the profile of patients with COPD and muscle wasting of our study proposing 
the possibility that muscle wasting in these two conditions involve different underlying mechanisms.

\section{Limitations of the study}

We have used FFMI measured by bioimpedance as a surrogate of muscle mass instead of a direct measurement of muscle mass. One of the most validated definitions of sarcopenia and severity of sarcopenia is based in BIA assessment of muscle mass [92]. This method has been validated against body composition assessed by deuterium dilution [93] and dual-energy X-ray absorptiometry [94] and shows very good correlation with other measurements of limb muscle mass in patients with COPD [95]. FFMI measured by bioimpedance is an independent predictor of skeletal muscle function and exercise capacity [96] and mortality [97] in patients with COPD. Moreover, it is a very sensitive method to detect undernutrition in these patients [98]. Values to differentiate muscle wasted patients from patients with preserved muscle mass based of FFMI have been established and validated in patients with COPD [93]. In our population, FFMI related to muscle function assessed as QMVC.

Physical activity (PA) can be seen as a confounding variable in this study. It was assessed with two questionnaires instead of using a direct measurement (i.e. activity monitors). PA assessed with the Voorrips questionnaire, designed to be use in elderly populations, showed lower physical activity levels in $\mathrm{COPD}_{\mathrm{L}}$. It was difficult to recruit patients with higher levels of PA assessed with this tool. Interestingly, there was no difference in the level of Activity of Daily Living assessed with the London Chest Activity of Daily Living Scale. Moreover, key DEGs identified in the present study showed no modification in response to exercise training in young [87] and elderly [86] subjects making it less likely that these changes were attributed to a lower PA level in this population.

Beside the efforts in matching the populations, healthy control subjects present differences in average cessation days and Pack/years in comparison to $\mathrm{COPD}_{\mathrm{L}}$. Environmental factors such as cigarette smoking may associate with peripheral muscle alterations [99]. However, it is unlikely to explain the differences in the transcriptome in our population as all three groups were matched for smoking status. Moreover, only one $\mathrm{COPD}_{\mathrm{L}}$ was an active smoker, whilst the other two groups included two active smokers each, which makes it less possible that this is a conditioning factor for muscle wasting in this group. Furthermore, no differences in the average cessation years, in cumulative history of smoking nor in age at smoking cessation (which may have important implications on outcomes) [100] were seen between $\mathrm{COPD}_{\mathrm{L}}$ and $\mathrm{COPD}_{\mathrm{N}}$. Therefore, it is unlikely that the time postsmoking cessation contributes to the differences in gene expression between these groups.

\section{Conclusions}

This study demonstrate that vastus lateralis of patients with COPD and muscle wasting overexpress genes related to inhibition of cell cycle and of cell growth while genes related to muscle formation and growth and energy production were down-regulated. This pattern is similar to observations associated with ageing which, suggests that premature ageing may play a role in muscle atrophy in COPD. This profile, together with several genes involved in inflammation signaling, were shared with the profile described in severely ill patients in the ICU which suggest both, that ICU patients may also experience cell senescence in response to inflammation and that inflammation may be a shared mechanism between COPD and ICU patients. These results may open new avenues for the treatment of muscle wasting in patients with COPD. The most challenging issue is to explore potential avenues for treatment and identify the timing to treat these with anti-aging agents considering that earlier diagnosis is a key for effective anti-aging therapy.

\section{Additional files}

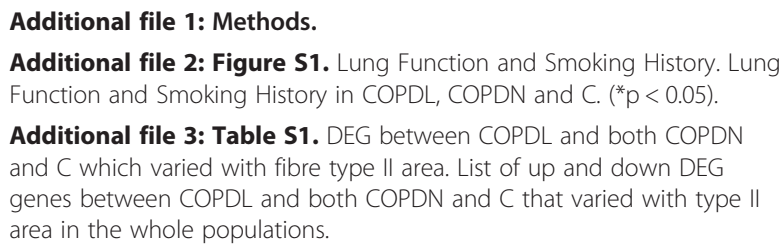

Additional file 3: Table S1. DEG between COPDL and both COPDN and $C$ which varied with fibre type $\|$ area. List of up and down DEG genes between COPDL and both COPDN and C that varied with type ॥ area in the whole populations.

Additional file 4: Table S2. DEG between COPDL and both COPDN and $C$ which varied with fibre type II percentage. List of up and down DEG genes between COPDL and both COPDN and $C$ that varied with type II fibre percentage in the whole populations.

Additional file 5: Table S3. DEG between COPDL and both COPDN and $C$ which varied with fibre muscle function measured as QMVC. List of up and down DEG genes between COPDL and both COPDN and C that varied with QMVC in the whole populations.

Additional file 6: Figure S2. qPCR graphics for the validated genes between COPDL and both other groups COPDN and C. qPCR validated genes in COPDL, COPDN and C. $\left({ }^{*} \mathrm{p}<0.05\right)$.

Additional file 7: Figure S3. Correlations between qPCR genes and QMVC. Correlations between QMVC ( $x$ axis) and qPCR gene expression corrected by GAPDH housekeeping gene $(\Delta \Delta \mathrm{Ct})$ in COPDL (o), COPDN $(\bullet)$ and $C$ ( $\bullet$ ) (y axis). Solid line represents regression line and dashed lines $95 \% \mathrm{Cl}$.

\section{Abbreviations}

mRNA: m Ribonucleic acid; COPD: Chronic obstructive pulmonary disease: FFMI: Fat free mass index; COPDL: Patients with COPD and low FFMl; COPDN: Patients with COPD and normal FFMI; C: Control subjects; HRQoL: Health related quality of life; BIA: Bioimpedance analysis; 6MWD: Six minute walking distance; QMVC: Quadriceps maximal voluntary contraction; SGRQ: Saint George's respiratory questionnaire; mMRC: Modified medical research council dyspnoea score; PA: Physical activity; PAv: Physical activity assessed with the Voorrips questionnaire; LCADL: London chest activity of daily living scale; PA : Physical activity assessed with the LCADL; PFP: Percent false positives; FDR: False discovery rate; GO: Gene ontology; qPCR: Real time polymerase chain reaction; $\Delta C T$ : Delta cycle threshold; $A D L$ : Activities of daily living; $F V_{1}$ : Forced expiratory volume in the first second; FVC: Forced vital capacity; RP: Rank products; DEGs: Differentially expressed genes; FC: Fold 
change; DNA: Deoxyribonucleic acid; ICU: Intensive care unit; $\mathrm{PaO}_{2}$ : Arterial oxygen partial pressure; $\mathrm{PaCO}_{2}$ : Arterial carbon dioxide partial pressure.

\section{Competing interests}

The authors have no competing interests to declare. This study was financially supported by the Chief Scientist Office (CSO 06/S1103/5) and the Fondo de Investigación Sanitaria (FIS) (PI08/0320).

\section{Authors' contributions}

Conception and design: RR, ED, RB, WM. Analysis and interpretation: RR, ED, $J M, D D, M C D R, R B, W M$. Drafting the manuscript for important intellectual contents: RR, ED, RB, WM. All authors read and approved the final manuscript.

\section{Acknowledgments}

The authors would like to thank the Chief Scientist Office (CSO 06/S1103/5) and the Fondo de Investigación Sanitaria (FIS 08/0320) for the financial support. The British Heart Foundation Centre of Research Excellence award is acknowledged for the data analysis support provided.

\section{Author details}

'ELEGI Colt Laboratory, Centre for Inflammation Research, The Queen's Medical Research Institute, University of Edinburgh, 47 Little France Crescent, Edinburgh, Scotland EH16 4TJ, UK. ${ }^{2}$ Centre for Cardiovascular Science, University of Edinburgh, Scotland, UK. ${ }^{3}$ Institut d'Investigacions Biomèdiques August Pi i Sunyer (IDIBAPS), Barcelona, Spain. ${ }^{4}$ Ciber de Enfermedades Respiratorias (CIBERES), Barcelona, Spain.

Received: 12 May 2014 Accepted: 24 October 2014

Published online: 08 January 2015

\section{References}

1. Agusti AG, Noguera A, Sauleda J, Sala E, Pons J, Busquets X. Systemic effects of chronic obstructive pulmonary disease. Eur Respir J. 2003;21:347-60.

2. Maltais F, Decramer M, Casaburi R, Barreiro E, Burelle Y, Debigare R, et al. An official american thoracic society/european respiratory society statement: update on limb muscle dysfunction in chronic obstructive pulmonary disease. Am J Respir Crit Care Med. 2014;189:e15-62.

3. Decramer M, Gosselink R, Troosters T, Schepers R. Peripheral muscle weakness is associated with reduced survival in COPD. Am J Respir Crit Care Med. 1998;157:A19.

4. Engelen MPKJ, Schols AMWJ, Does JD, Wouters EFM. Skeletal muscle weakness is associated with wasting of extremity fat-free mass but not with airflow obstruction in patients with chronic obstructive pulmonary disease. Am J Clin Nutr. 2000;71:733-8.

5. Bernard S, Leblanc P, Whittom F, Carrier G, Jobin J, Belleau R, et al. Peripheral muscle weakness in patients with chronic obstructive pulmonary disease. Am J Respir Crit Care Med. 1998;158:629-34.

6. Vilaro J, Rabinovich R, Gonzalez-deSuso JM, Troosters T, Rodriguez D, Barbera JA, et al. Clinical assessment of peripheral muscle function in patients with chronic obstructive pulmonary disease. Am J Phys Med Rehabil. 2009;88:39-46.

7. Schols AMWJ, Soeters PB, Dingemans AMC, Mostert R, Frantzen PJ, Wouters EFM. Prevalence and characteristics of nutritional depletion in patients with stable COPD eligible for pulmonary rehabilitation. Am Rev Respir Dis. 1993;147:1151-6.

8. Baarends EM, Schols AM, Mostert R, Wouters EF. Peak exercise response in relation to tissue depletion in patients with chronic obstructive pulmonary disease. Eur Respir J. 1997;10:2807-13.

9. Kobayashi A, Yoneda T, Yoshikawa M, Ikuno M, Takenaka H, Fukuoka A, et al. The relation of fat-free mass to maximum exercise performance in patients with chronic obstructive pulmonary disease. Lung. 2000;178:119-27.

10. Schols AM, Mostert R, Soeters PB, Wouters EF. Body composition and exercise performance in patients with chronic obstructive pulmonary disease. Thorax. 1991;46:695-9.

11. Mostert R, Goris A, Weling-Scheepers C, Wouters EF, Schols AM. Tissue depletion and health related quality of life in patients with chronic obstructive pulmonary disease. Respir Med. 2000;94:859-67.

12. Marquis K, Debigare R, Lacasse $Y$, Leblanc $P$, Jobin J, Carrier G, et al. Midthigh muscle cross-sectional area is a better predictor of mortality than body mass index in patients with chronic obstructive pulmonary disease. Am J Respir Crit Care Med. 2002;166:809-13.
13. Mador MJ. Muscle mass, not body weight, predicts outcome in patients with chronic obstructive pulmonary disease. Am J Respir Crit Care Med. 2002;166:787-9.

14. Engelen MPKJ, Schols AMWJ, Baken WC, Wesseling GJ, Wouters EFM Nutritional depletion in relation to respiratory and peripheral skeletal muscle function in out-patients with COPD. Eur Respir J. 1994;7:1793-7.

15. Eid AA, lonescu AA, Nixon LS, Lewis-Jenkins V, Matthews SB, Griffiths TL, et al. Inflammatory response and body composition in chronic obstructive pulmonary disease. Am J Respir Crit Care Med. 2001;164:1414-8.

16. Jakobsson $P$, Jorfeldt $L$, Brundin A. Skeletal muscle metabolits and fibre types in patients with advanced chronic obstructive pulmonary disease (COPD), with and without chronic respiratory failure. Eur Respir J. 1990;3:192-6.

17. Simard C, Maltais F, Leblanc P, Simard P, Jobin J. Mitochondrial and capillarity changes in vastus lateralis muscle of COPD patients: electron microscopy study. Med Sci Sports Exerc. 1996;28:S95.

18. Rabinovich RA, Bastos R, Ardite E, Orozco-Levi M, Gea J, Vilar£ J, et al. Mitochondrial dysfunction in COPD patients with low body mass index. Eur Respir J. 2007;29:643-50.

19. Puente-Maestu L, Perez-Parra J, Godoy R, Moreno N, Tejedor A, GonzalezAragoneses F, et al. Abnormal mitochondrial function in locomotor and respiratory muscles of COPD patients. Eur Respir J. 2009;33:1045-52.

20. Ito K, Mercado N. STOP accelerating lung aging for the treatment of COPD. Exp Gerontol. 2014; http://dx.doi.org/10.1016/j.exger.2014.03.014.

21. Theriault ME, Pare ME, Maltais F, Debigare R. Satellite cells senescence in limb muscle of severe patients with COPD. PloS One. 2012;7:e39124.

22. Bernard S, Whittom F, Leblanc P, Jobin J, Belleau R, Berube C, et al. Aerobic and strength training in patients with chronic obstructive pulmonary disease. Am J Respir Crit Care Med. 1999;159:896-901.

23. Decramer M. Global strategy for the diagnosis, management, and prevention of chronic obstructive pulmonary disease (updated 2014). 2014; www.goldcopd.com.

24. ATS Committee on Proficiency Standards for Clinical Pulmonary Function Laboratories. ATS statement: guidelines for the six-minute walk test. Am J Respir Crit Care Med. 2002;166:111-7.

25. Spruit MA, Gosselink R, Troosters T, Kasran A, Gayan-Ramirez G, Bogaerts P, et al. Muscle force during an acute exacerbation in hospitalised patients with COPD and its relationship with CXCL8 and IGF-I. Thorax. 2003;58:752-6.

26. Jones PW, Quirk FH, Baveystock CM, Littlejohns P. A self-complete measure of health status for chronic airflow limitation. Am Rev Respir Dis. 1992;145:1321-7.

27. Voorrips LE, Ravelli AC, Dongelmans PC, Deurenberg P, Van Staveren WA. A physical activity questionnaire for the elderly. Med Sci Sports Exerc. 1991;23:974-9.

28. Garrod R, Bestall JC, Paul EA, Wedzicha JA, Jones PW. Development and validation of a standardized measure of activity of daily living in patients with severe COPD: the London chest activity of daily living scale (LCADL). Respir Med. 2000;94:589-96.

29. Schols AM, Broekhuizen R, Weling-Scheepers CA, Wouters EF. Body composition and mortality in chronic obstructive pulmonary disease. Am J Clin Nutr. 2005;82:53-9.

30. Toth ZE, Mezey E. Simultaneous visualization of multiple antigens with tyramide signal amplification using antibodies from the same species. J Histochem Cytochem. 2007;55:545-54.

31. Team RDC. A Language and Environment for Statistical Computing. $\mathrm{R}$ Foundation for Statistical Computing. In: Book A Language and Environment for Statistical Computing. Vienna, Austria: R Foundation for Statistical Computing; 2005.

32. Gentleman RC, Carey VJ, Bates DM, Bolstad B, Dettling M, Dudoit S, et al. Bioconductor: open software development for computational biology and bioinformatics. Genome Biol. 2004;5:R80.

33. Breitling $R$, Armengaud $P$, Amtmann A, Herzyk P. Rank products: a simple, yet powerful, new method to detect differentially regulated genes in replicated microarray experiments. FEBS Lett. 2004;573:83-92.

34. Hong F, Breitling R, McEntee CW, Wittner BS, Nemhauser JL, Chory J. RankProd: a bioconductor package for detecting differentially expressed genes in meta-analysis. Bioinformatics. 2006;22:2825-7.

35. Gallagher IJ, Scheele C, Keller P, Nielsen AR, Remenyi J, Fischer CP, et al. Integration of microrna changes in vivo identifies novel molecular features of muscle insulin resistance in type 2 diabetes. Genome Med. 2010;2:9. 
36. Calvano SE, Xiao W, Richards DR, Felciano RM, Baker HV, Cho RJ, et al. A network-based analysis of systemic inflammation in humans. Nature. 2005:437:1032-7

37. Doucet M, Russell AP, Leger B, Debigare R, Joanisse DR, Caron MA, et al. Muscle atrophy and hypertrophy signaling in patients with chronic obstructive pulmonary disease. Am J Respir Crit Care Med. 2007;176:261-9.

38. Dong C, Li Q, Lyu SC, Krensky AM, Clayberger C. A novel apoptosis pathway activated by the carboxyl terminus of p21. Blood. 2005;105:1187-94.

39. Ebert SM, Dyle MC, Kunkel SD, Bullard SA, Bongers KS, Fox DK, et al. Stress-induced skeletal muscle Gadd45a expression reprograms myonuclei and causes muscle atrophy. J Biol Chem. 2012;287:27290-301.

40. Caiozzo VJ, Utkan A, Chou R, Khalafi A, Chandra H, Baker M, et al. Effects of distraction on muscle length: mechanisms involved in sarcomerogenesis. Clin Orthop Relat Res 2002:S133-145

41. Bongers KS, Fox DK, Ebert SM, Kunkel SD, Dyle MC, Bullard SA, et al. Skeletal muscle denervation causes skeletal muscle atrophy through a pathway that involves both Gadd45a and HDAC4. Am J Physiol Endocrinol Metab. 2013:305:E907-15.

42. Calura E, Cagnin S, Raffaello A, Laveder P, Lanfranchi G, Romualdi C. Meta-analysis of expression signatures of muscle atrophy: gene interaction networks in early and late stages. BMC Genomics. 2008;9:630.

43. De Aguilar JL G, Niederhauser-Wiederkehr C, Halter B, De Tapia M, Di Scala $F$, Demougin $P$, et al. Gene profiling of skeletal muscle in an amyotrophic lateral sclerosis mouse model. Physiol Genomics. 2008;32:207-18.

44. Ohsawa Y, Hagiwara H, Nakatani M, Yasue A, Moriyama K, Murakami T, et al. Muscular atrophy of caveolin-3-deficient mice is rescued by myostatin inhibition. J Clin Invest. 2006;1 16:2924-34.

45. Thomas M, Langley B, Berry C, Sharma M, Kirk S, Bass J, et al. Myostatin, a negative regulator of muscle growth, functions by inhibiting myoblast proliferation. J Biol Chem. 2000;275:40235-43.

46. Dotto GP. p21(WAF1/Cip1): more than a break to the cell cycle? Biochim Biophys Acta. 2000;1471:M43-56.

47. Gartel AL, Tyner AL. The role of the cyclin-dependent kinase inhibitor p21 in apoptosis. Mol Cancer Ther. 2002;1:639-49.

48. Wang A, Gu J, Judson-Kremer K, Powell KL, Mistry H, Simhambhatla P, et al. Response of human mammary epithelial cells to DNA damage induced by BPDE: involvement of novel regulatory pathways. Carcinogenesis. 2003;24:225-34

49. Okamoto Y, Chaves A, Chen J, Kelley R, Jones K, Weed HG, et al. Transgenic mice with cardiac-specific expression of activating transcription factor 3 , a stress-inducible gene, have conduction abnormalities and contractile dysfunction. Am J Pathol. 2001;159:639-50.

50. Laure L, Suel L, Roudaut C, Bourg N, Ouali A, Bartoli M, et al. Cardiac ankyrin repeat protein is a marker of skeletal muscle pathological remodelling. FEBS J. 2009:276:669-84

51. Wu CL, Kandarian SC, Jackman RW. Identification of genes that elicit disuse muscle atrophy via the transcription factors p50 and Bcl-3. PloS One. 2011;6:e16171

52. Timchenko NA, Wilde M, Nakanishi M, Smith JR, Darlington GJ. CCAAT/ enhancer-binding protein alpha (C/EBP alpha) inhibits cell proliferation through the p21 (WAF-1/CIP-1/SDI-1) protein. Genes Dev. 1996;10:804-15.

53. Timchenko NA, Harris TE, Wilde M, Bilyeu TA, Burgess-Beusse BL, Finegold MJ, et al. CCAAT/enhancer binding protein alpha regulates p21 protein and hepatocyte proliferation in newborn mice. Mol Cell Biol. 1997;17:7353-61.

54. Agusti AG, Sauleda J, Miralles C, Gomez C, Togores B, Sala E, et al. Skeletal muscle apoptosis and weight loss in chronic obstructive pulmonary disease. Am J Respir Crit Care Med. 2002;166:485-9.

55. Barreiro E, Ferrer D, Sanchez F, Minguella J, Marin-Corral J, Martinez-Llorens $J$, et al. Inflammatory cells and apoptosis in respiratory and limb muscles of patients with COPD. J Appl Physiol. 2011;111:808-17.

56. Gosker HR, Kubat B, Schaart G, van der Vusse GJ, Wouters EF, Schols AM. Myopathological features in skeletal muscle of patients with chronic obstructive pulmonary disease. Eur Respir J. 2003;22:280-5.

57. Suzuki A, Tsutomi Y, Akahane K, Araki T, Miura M. Resistance to Fas-mediated apoptosis: activation of caspase 3 is regulated by cell cycle regulator p21WAF1 and IAP gene family ILP. Oncogene. 1998;17:931-9.

58. Hubal MJ, Chen TC, Thompson PD, Clarkson PM. Inflammatory gene changes associated with the repeated-bout effect. Am J Physiol Regul Integr Comp Physiol. 2008;294:R1628-37.
59. Kivela $R$, Kyrolainen $H$, Selanne $H$, Komi PV, Kainulainen $H$, Vihko V. A single bout of exercise with high mechanical loading induces the expression of Cyr61/CCN1 and CTGF/CCN2 in human skeletal muscle. J Appl Physiol (1985). 2007;103:1395-401.

60. Kivela R, Silvennoinen M, Lehti M, Jalava S, Vihko V, Kainulainen H. Exerciseinduced expression of angiogenic growth factors in skeletal muscle and in capillaries of healthy and diabetic mice. Cardiovasc Diabetol. 2008;7:13.

61. O'Connor RS, Mills ST, Jones KA, Ho SN, Pavlath GK. A combinatorial role for NFAT5 in both myoblast migration and differentiation during skeletal muscle myogenesis. J Cell Sci. 2007;120:149-59.

62. Rayssac A, Neveu C, Pucelle M, Van den Berghe L, Prado-Lourenco L, Arnal JF, et al. IRES-based vector coexpressing FGF2 and Cyr61 provides synergistic and safe therapeutics of lower limb ischemia. Mol Ther. 2009;17:2010-9.

63. Lehnert SA, Byrne KA, Reverter A, Nattrass GS, Greenwood PL, Wang YH, et al. Gene expression profiling of bovine skeletal muscle in response to and during recovery from chronic and severe undernutrition. J Anim Sci. 2006:84:3239-50

64. Magnusson C, Svensson A, Christerson U, Tagerud S. Denervation-induced alterations in gene expression in mouse skeletal muscle. Eur J Neurosci. 2005;21:577-80

65. Lobel M, Bauer S, Meisel C, Eisenreich A, Kudernatsch R, Tank J, et al. Ccn1: a novel inflammation-regulated biphasic immune cell migration modulator. Cellular and molecular life sciences: CMLS. 2012;69:3101-13.

66. Fermoselle C, Rabinovich R, Ausin P, Puig-Vilanova E, Coronell C, Sanchez F, et al. Does oxidative stress modulate limb muscle atrophy in severe COPD patients? Eur Respir J. 2012;40:851-62.

67. Barreiro E, Rabinovich R, Marin-Corral J, Barbera JA, Gea J, Roca J. Chronic endurance exercise induces quadriceps nitrosative stress in patients with severe COPD. Thorax. 2009:64:13-9.

68. Rabinovich RA, Ardite E, Troosters T, Carb \& N, Alonso J, de Suso JM G, et al. Reduced muscle redox capacity after endurance training in copd patients. American Journal of Respiratory and Critical Care Medicine. 2001:164:1114-8.

69. Rabinovich RA, Ardite E, Mayer AM, Figueras Polo M, Vilarc J, Argiles JM, et al. Training depletes muscle glutathione in COPD patients with low body mass index. Respiration. 2006;73:757-61.

70. Paine A, Eiz-Vesper B, Blasczyk R, Immenschuh S. Signaling to heme oxygenase-1 and its anti-inflammatory therapeutic potential. Biochem Pharmacol. 2010;80:1895-903.

71. Rabinovich RA, Figueras M, Ardite E, Carbo N, Troosters T, Filella X, et al. Increased tumour necrosis factor-alpha plasma levels during moderateintensity exercise in COPD patients. Eur Respir J. 2003:21:789-94.

72. Montes De Oca M, Torres SH, De Sanctis J, Mata A, Hernandez N, Talamo C. Skeletal muscle inflammation and nitric oxide in patients with COPD. Eur Respir J. 2005;26:390-7.

73. Remels $\mathrm{AH}$, Gosker HR, Schrauwen P, Hommelberg PP, Sliwinski P, Polkey M, et al. TNF-alpha impairs regulation of muscle oxidative phenotype: implications for cachexia? FASEB J. 2010;24:5052-62.

74. Agusti A, Morla M, Sauleda J, Saus C, Busquets X. NF-kappaB activation and iNOS upregulation in skeletal muscle of patients with COPD and low body weight. Thorax. 2004;59:483-7.

75. Plant PJ, Brooks D, Faughnan M, Bayley T, Bain J, Singer L, et al. Cellular markers of muscle atrophy in chronic obstructive pulmonary disease. Am J Respir Cell Mol Biol. 2010;42:461-71.

76. Vogiatzis I, Simoes DC, Stratakos G, Kourepini E, Terzis G, Manta P, et al Effect of pulmonary rehabilitation on muscle remodelling in cachectic patients with COPD. Eur Respir J. 2010;36:301-10.

77. Dogra C, Changotra H, Wedhas N, Qin X, Wergedal JE, Kumar A. TNF-related weak inducer of apoptosis (TWEAK) is a potent skeletal muscle-wasting cytokine. FASEB J. 2007;21:1857-69.

78. Mittal A, Bhatnagar S, Kumar A, Lach-Trifilieff E, Wauters S, Li H, et al. The TWEAK-Fn14 system is a critical regulator of denervation-induced skeleta muscle atrophy in mice. J Cell Biol. 2010;188:833-49.

79. Park CY, Pierce SA, Von Drehle M, Ivey KN, Morgan JA, Blau HM, et al. skNAC, a Smyd1-interacting transcription factor, is involved in cardiac development and skeletal muscle growth and regeneration. Proc Natl Acad Sci U S A. 2010;107:20750-5.

80. Wu Z, Nagano I, Takahashi Y. Candidate genes responsible for common and different pathology of infected muscle tissues between Trichinella spiralis and T. pseudospiralis infection. Parasitol Int. 2008;57:368-78. 
81. Crul T, Spruit MA, Gayan-Ramirez G, Quarck R, Gosselink R, Troosters T, et al. Markers of inflammation and disuse in vastus lateralis of chronic obstructive pulmonary disease patients. Eur J Clin Invest. 2007;37:897-904

82. Theriault ME, Pare ME, Lemire BB, Maltais F, Debigare R. Regenerative defect in vastus lateralis muscle of patients with chronic obstructive pulmonary disease. Respir Res. 2014;15:35.

83. Fredriksson K, Tjader I, Keller P, Petrovic N, Ahlman B, Scheele C, et al. Dysregulation of mitochondrial dynamics and the muscle transcriptome in ICU patients suffering from sepsis induced multiple organ failure. PloS One. 2008:3:e3686.

84. Stephens NA, Gallagher IJ, Rooyackers O, Skipworth RJ, Tan BH, Marstrand T, et al. Using transcriptomics to identify and validate novel biomarkers of human skeletal muscle cancer cachexia. Genome Med. 2010:2:1.

85. Welle S, Brooks Al, Delehanty JM, Needler N, Bhatt K, Shah B, et al. Skeletal muscle gene expression profiles in 20-29 year old and 65-71 year old women. Exp Gerontol. 2004;39:369-77.

86. Melov S, Tarnopolsky MA, Beckman K, Felkey K, Hubbard A. Resistance exercise reverses aging in human skeletal muscle. PloS One. 2007;2:e465.

87. Keller P, Vollaard NB, Gustafsson T, Gallagher IJ, Sundberg CJ, Rankinen T, et al. A transcriptional map of the impact of endurance exercise training on skeletal muscle phenotype. J Appl Physiol. 2011;110:46-59.

88. Debigare R, Maltais F, Cote CH, Michaud A, Caron MA, Mofarrahi M, et al. Profiling of mRNA expression in quadriceps of patients with COPD and muscle wasting. Copd. 2008;5:75-84.

89. Crul T, Testelmans D, Spruit MA, Troosters T, Gosselink R, Geeraerts I, et al. Gene expression profiling in vastus lateralis muscle during an acute exacerbation of COPD. Cell Physiol Biochem. 2010;25:491-500.

90. Kuro-o M, Matsumura Y, Aizawa H, Kawaguchi H, Suga T, Utsugi T, et al. Mutation of the mouse klotho gene leads to a syndrome resembling ageing. Nature. 1997;390:45-51.

91. Kim JS, Kim EJ, Kim HJ, Yang JY, Hwang GS, Kim CW. Proteomic and metabolomic analysis of $\mathrm{H} 2 \mathrm{O} 2$-induced premature senescent human mesenchymal stem cells. Exp Gerontol. 2011;46:500-10.

92. Janssen I, Heymsfield SB, Ross R. Low relative skeletal muscle mass (sarcopenia) in older persons is associated with functional impairment and physical disability. J Am Geriatr Soc. 2002;50:889-96.

93. Schols AM, Wouters EF, Soeters PB, Westerterp KR. Body composition by bioelectrical-impedance analysis compared with deuterium dilution and skinfold anthropometry in patients with chronic obstructive pulmonary disease. Am J Clin Nutr. 1991;53:421-4.

94. Bosaeus I, Wilcox G, Rothenberg E, Strauss BJ. Skeletal muscle mass in hospitalized elderly patients: Comparison of measurements by single-frequency BIA and DXA. Clin Nutr. 2014;33:426-31.

95. Seymour JM, Ward K, Sidhu PS, Puthucheary Z, Steier J, Jolley CJ, et al. Ultrasound measurement of rectus femoris cross-sectional area and the relationship with quadriceps strength in COPD. Thorax. 2009;64:418-23.

96. Franssen FM, Broekhuizen R, Janssen PP, Wouters EF, Schols AM. Effects of whole-body exercise training on body composition and functional capacity in normal-weight patients with COPD. Chest. 2004;125:2021-8.

97. Slinde F, Gronberg A, Engstrom CP, Rossander-Hulthen L, Larsson S. Body composition by bioelectrical impedance predicts mortality in chronic obstructive pulmonary disease patients. Respir Med. 2005;99:1004-9.

98. Thibault R, Le Gallic E, Picard-Kossovsky M, Darmaun D, Chambellan A. [Assessment of nutritional status and body composition in patients with COPD: comparison of several methods]. Rev Mal Respir. 2010;27:693-702.

99. Montes De Oca M, Loeb E, Torres SH, De Sanctis J, Hernandez N, Talamo C. Peripheral muscle alterations in non-COPD smokers. Chest. 2008;133:13-8.

100. Doll R, Peto R, Boreham J, Sutherland I. Mortality in relation to smoking: 50 years' observations on male British doctors. BMJ. 2004:328:1519.

\section{Submit your next manuscript to BioMed Central and take full advantage of:}

- Convenient online submission

- Thorough peer review

- No space constraints or color figure charges

- Immediate publication on acceptance

- Inclusion in PubMed, CAS, Scopus and Google Scholar

- Research which is freely available for redistribution

Submit your manuscript at www.biomedcentral.com/submit 